E International

\title{
Overcoming Obstacles to Implementing SMS
}

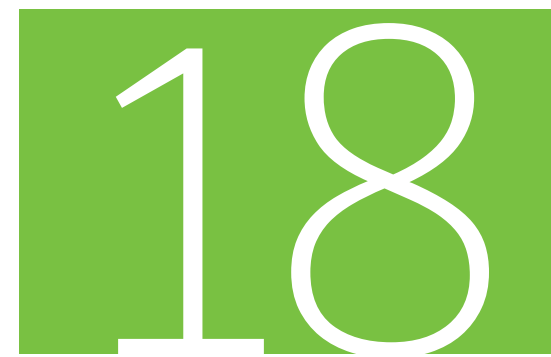

Discussion Paper 2017 • 18

Jouni Lappalainen

Special Adviser,

Finnish Transport Safety Agency 


\title{
F International Transport Forum
}

\section{Overcoming Obstacles to Implementing SMS}

\section{Discussion Paper 2017-18}

\author{
Prepared for the Roundtable on \\ Safety Management Systems \\ (23-24 March 2017 - Paris)
}

\section{Jouni Lappalainen}

Special Adviser

Finnish Transport Safety Agency, Finland

August 2017 


\section{The International Transport Forum}

The International Transport Forum is an intergovernmental organisation with 59 member countries. It acts as a think tank for transport policy and organises the Annual Summit of transport ministers. ITF is the only global body that covers all transport modes. The ITF is politically autonomous and administratively integrated with the OECD.

The ITF works for transport policies that improve peoples' lives. Our mission is to foster a deeper understanding of the role of transport in economic growth, environmental sustainability and social inclusion and to raise the public profile of transport policy.

The ITF organises global dialogue for better transport. We act as a platform for discussion and pre-negotiation of policy issues across all transport modes. We analyse trends, share knowledge and promote exchange among transport decision-makers and civil society. The ITF's Annual Summit is the world's largest gathering of transport ministers and the leading global platform for dialogue on transport policy.

The Members of the Forum are: Albania, Armenia, Argentina, Australia, Austria, Azerbaijan, Belarus, Belgium, Bosnia and Herzegovina, Bulgaria, Canada, Chile, China (People's Republic of), Croatia, Czech Republic, Denmark, Estonia, Finland, France, Former Yugoslav Republic of Macedonia, Georgia, Germany, Greece, Hungary, Iceland, India, Ireland, Israel, Italy, Japan, Kazakhstan, Korea, Latvia, Liechtenstein, Lithuania, Luxembourg, Malta, Mexico, Republic of Moldova, Montenegro, Morocco, the Netherlands, New Zealand, Norway, Poland, Portugal, Romania, Russian Federation, Serbia, Slovak Republic, Slovenia, Spain, Sweden, Switzerland, Turkey, Ukraine, the United Arab Emirates, the United Kingdom and the United States.

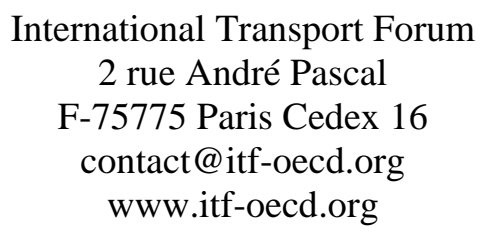

\section{ITF Discussion Papers}

ITF Discussion Papers make economic research, commissioned or carried out in-house at ITF, available to researchers and practitioners. They describe preliminary results or research in progress by the author(s) and are published to stimulate discussion on a broad range of issues on which the ITF works. Any findings, interpretations and conclusions expressed herein are those of the authors and do not necessarily reflect the views of the International Transport Forum or the OECD. Neither the OECD, ITF nor the authors guarantee the accuracy of any data or other information contained in this publication and accept no responsibility whatsoever for any consequence of their use. This document and any map included herein are without prejudice to the status of or sovereignty over any territory, to the delimitation of international frontiers and boundaries and to the name of any territory, city or area. Comments on Discussion Papers are welcome. 


\section{Acknowledgements}

I want to express my gratitude to Mr Alain Lumbroso and the International Transport Forum for giving me this opportunity to write this paper to the SMS Roundtable. I want to express my appreciation to my colleagues Mr Aleksi Uttula, Ms Sanna Ström, Ms Kirsi Pajunen, Mr Jouko Linnasaari, Mr Ilkka Kaakinen in the Finnish Transport Safety Agency for giving me valuable information during the preparation of this paper. In addition, I am grateful for Dr Anna-Maria Teperi for her supportive and constructive comments on my paper. 


\begin{abstract}
This paper discusses obstacles faced in implementing SMS and uses concrete examples to show how to overcome them across all modes of transport (air, maritime, rail and road) in leading countries, particularly ITF member countries.

The difficulties and problems in implementing SMS can originate from the specific cultural features of an organisation or an occupation. The cultural features can become either an enabler or a barrier for implementation of the safety management system. By understanding the cultural features better, the difficulties and problems in implementing safety management systems could be resolved.

In order to avoid that particular cultural features become a barrier for implementing safety management systems the employees' experience and expertise should be employed in the implementation work more intensively. Key enablers for safety improvements would involve all organisational levels in the identification, discussion and implementation of potential safety issues.

New thinking is needed in safety management and, particularly, in incident reporting. Focusing on positive human factors and understanding humans as a resource of successful performance could motivate and encourage employees to report incidents more actively and thus promote rooting of positive safety culture in organisations.

No company can manage implementing the safety management system properly using only its own resources. Co-operation of companies is needed and regulatory agencies should provide support for co-operation. The industries' voluntary co-operation programmes have proved to be effective and valuable for overcoming any obstacles in the implementation of safety management systems.
\end{abstract}




\section{Table of contents}

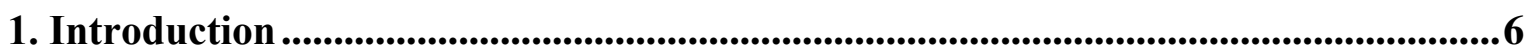

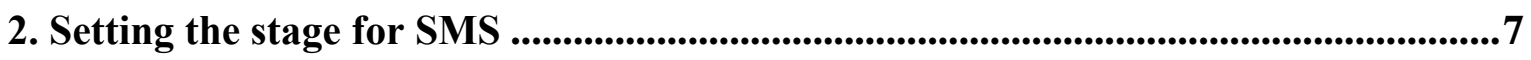

2.1. Regulatory framework of safety management systems in different transport modes 7

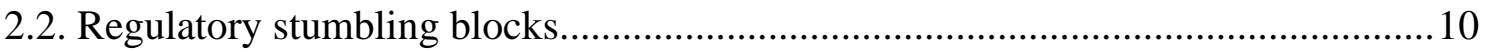

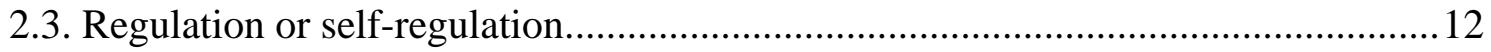

2.4. Safety culture as a prerequisite of safety management ….................................... 13

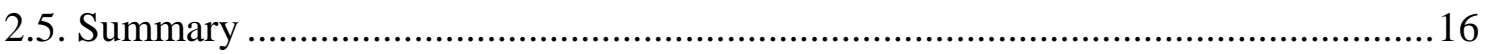

3. SMS obstacles for operators..................................................................................17

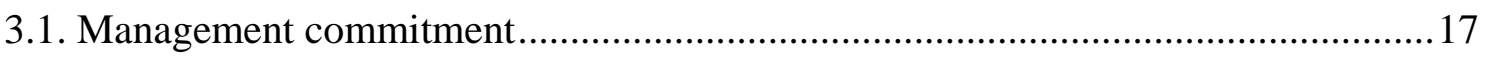

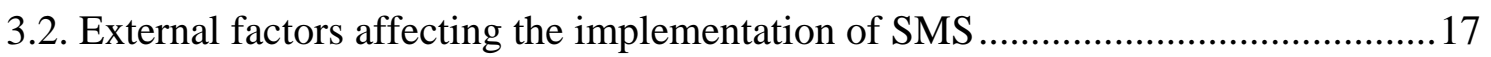

3.3. Multinational crews and the transitive nature of workforce .................................. 19

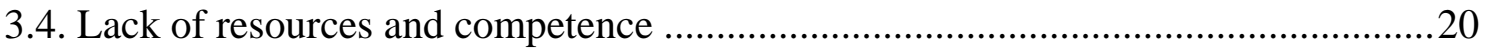

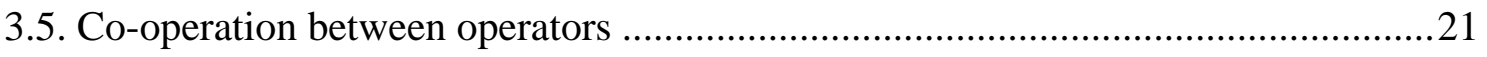

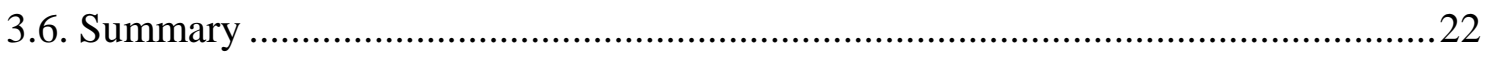

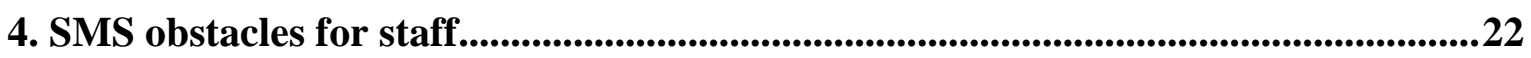

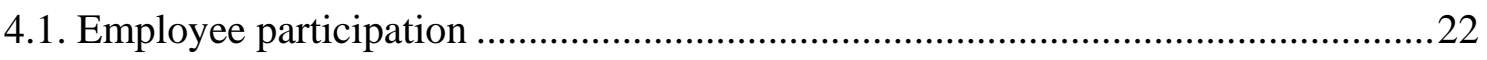

4.2. Conflicting cultural approaches, a barrier for implementing SMS .........................2 23

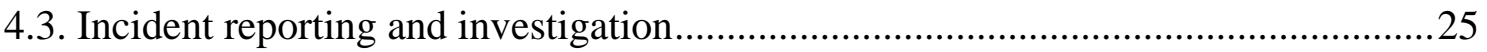

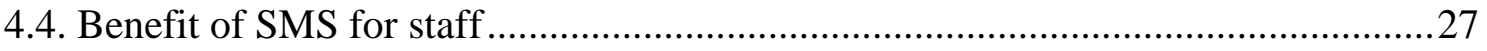

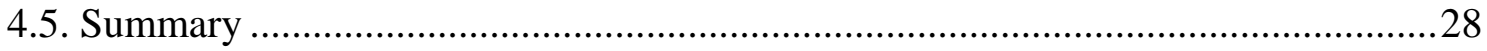

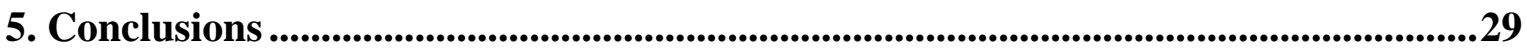

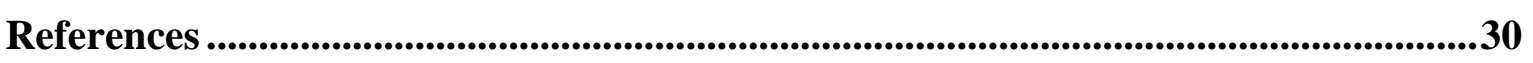

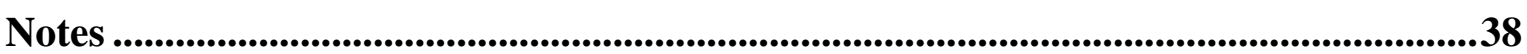




\section{Introduction}

The purpose of this paper is to examine the obstacles to implementing safety management systems and to discuss solutions for overcoming those obstacles in four modes of transport: aviation, maritime, rail and road. These four transport modes can be considered to represent safety critical industries.

According to Reiman and Oedewald (2009), a safety critical organisation can be defined as any organisation that has to deal with or control such hazards that can cause significant harm to the environment, public or personnel. Safety critical organisations aim to control their risks and manage safety (Reiman and Oedewald, 2009).

In addition, aviation (global) and rail transportation in Europe can be considered as high reliability industries (Amalberti, 2001; Lofquist, 2008; Salokorpi and Rytkönen, 2010). Those safety critical organisations that have achieved superior safety performance can be called high reliability organisations. The high reliability of those organisations has been ensured by common management structures, supportive organisational cultures, and learning environments (Weick and Sutcliffe, 2007; Lofquist, 2008; Salokorpi and Rytkönen 2010). What is more, according to Amalberti (2001), regularly scheduled civilian flights and rail transportation in Europe represent ultra-safe systems, where the risk of disaster is below one accident per 100000 or even one million safety units.

In order to ensure an appropriate level of safety, the safety critical organisations have implemented different types of safety management systems (Oedewald and Reiman, 2007; Salokorpi and Rytkönen, 2010; Lappalainen, 2016). Many definitions exist for safety management (Reiman and Oedewald, 2009; Grote, 2012). ICAO (2013) has defined safety management as a systematic approach to managing safety, including the necessary organisational structures, accountabilities, policies and procedures. (ICAO, 2013). Respectively, in the ISM Code, safety management system is defined as a structured and documented system enabling company personnel to effectively implement the company safety and environmental protection policy.

Crucial elements in safety management systems are incident reporting and investigation, employee participation, as well as standards and procedures (Wiegmann et al., 2002; Bhattacharya, 2009; Grote, 2012; Lappalainen, 2016). However, considerable difficulties and problems have been reported in the implementation of those elements. Numerous studies in different industries have found that incidents are not reported completely, there are shortages in employee participation, and the rules and procedures are not followed in daily operations as required in safety management systems (see, for example, Anderson, 2003; Sanne, 2007; Paris MoU, 2008; Bhattacharya, 2009; Teperi and Leppänen, 2010; Oltedal, 2011; Grote, 2012).

This paper discusses how these difficulties and problems can originate from the specific cultural features of an organisation or an occupation. The cultural features can become either an enabler or a barrier for implementation of the safety management system (Alvesson, 2002; Grote, 2012; Lappalainen, 2016). By understanding the cultural features better, the difficulties and problems in implementing safety management systems could be resolved (ICAO, 2013; Lappalainen, 2016). This paper is structured as follows:

- Section 2 discusses the legislative and regulatory framework for safety management systems.

- Section 3 discusses the obstacles for operators.

- Section 4 discusses the obstacles to implementing SMS encountered by employees.

- Section 5 presents the conclusions of this paper. 
This study is based on a literature review of previous studies and some interviews of representatives for the Finnish Transport Safety Agency and other stakeholders.

\section{Setting the stage for SMS}

First, this section provides an introduction to the legislative and regulatory framework for safety management. In aviation, rail and maritime transportation today, safety management systems are based on mandatory legislation. In road transportation safety management is mainly based on voluntary efforts by progressive companies.

Second, this section discusses the types of problems and difficulties that have appeared in the implementation of safety management based on a high regulatory burden and excessive inspections. And third, it examines how self-regulation has been proposed to tackle the problems associated with regulatory burden.

Fourth, this section presents the different perspectives of safety culture and how it affects the success of implementation of safety management systems.

\subsection{Regulatory framework of safety management systems in different transport modes}

In European aviation, safety management systems were made compulsory for operators and authorities with an EU Regulation in 2012. The EU requirements are based on ICAO recommendations for safety management systems. Based on the EU Regulation, authorities are required to implement a State Safety Plan (SSP) and operators must establish a safety management system (SMS) (EASA, 2016). The first EASA SSP/SMS requirements have been adopted in the form of authority and organisation requirements with Regulation (EU) 290/2012 in the domain of flight and cabin crew, and with Regulation (EU) 965/2012 in the domain of air operations. The requirements will be progressively extended to other sectors of the aviation system.

ICAO published a new Annex (19) dedicated to Safety Management in 2013. The Annex gathers in one document all safety management requirements that were previously spread across various ICAO Annexes. Annex 19 comes with detailed guidance in the form of a "Safety Management Manual".

In European rail transportation, safety management systems have been based on the European Railway Safety Directive enacted in 2004 (2004/49/EC; El-Koursi et al 2007). The Directive requires that all railway undertakings (who run train services) and infrastructure managers (who maintain the railway network) in European Union member states implement a safety management system that meets certain criteria and is certified by the relevant national safety authority (El-Koursi et al 2007). The European Railway Safety Directive aimed to harmonise safety management practises among European countries in order to facilitate the liberalisation of the railway industry and creation of an effective internal market for railway services in Europe (El-Koursi et al 2007).

The European Railway Safety Directive has been newly revised (Directive (EU), 2016/798). The Directive provides a new structure for the elements of safety management. The new structure follows the common structure of ISO management standards. The human factors element is included as a new approach in the Directive. The Directive requires that the impact of human factors must be taken into consideration in the implementation of safety management systems. The safety management system should ensure that human capabilities and limitations and the influences on human performance are addressed by applying human factors knowledge and using recognised methods. (Directive (EU), 2016/798). 
It is noteworthy that the safety management requirements are similar for all railway infrastructure managers and railway undertakings irrespective of their size or other operating conditions of their business. However, the Directive provides freedom to the organisations to adapt their safety management systems according to the type, extent and area of operations as well as other operating conditions (Directive (EU), 2016/798).

In maritime transportation, mandatory safety management systems have been used for about twenty years. Safety management systems became compulsory in the maritime industry as a reaction to many serious maritime accidents and other problems in maritime safety culture in the 1980's and early 1990's. The main trigger for safety management in the maritime industry was the accident to Herald of Free Enterprise in 1987. The International Maritime Organisation (IMO) enacted the ISM Code that provides an international standard for the safe management and operation of ships and for the prevention of pollution. The ISM Code requires that "every Company should develop, implement and maintain a Safety Management System (SMS)" (IMO, 1993).

The ISM Code is incorporated in the international SOLAS Convention, in which the Code forms Chapter IX. It is noteworthy that the ISM Code is considered to be the first maritime regulatory instrument that determines specified responsibilities for a company and its management with regard to safety (Anderson, 2003; see also Schröder-Hinrichs et al., 2015). The member states of IMO are responsible for implementing the ISM Code in their national legislation.

The ISM Code was established in the early 1990's. Since then, the Code has not been developed much further, which has also raised some criticism (Schröeder-Hinrich et al., 2013). The Code has been amended several times, most recently in June 2013, but the amendments have been very moderate (Schröeder-Hinrich et al., 2013; Lappalainen, 2016; Interview AU 18.10.2016). According to Schröeder-Hinrich et al. (2013), the Code reflects the state of the art of the early 1990 's. Any new safety theories have not been taken into account.

Another criticism has focused on the content of the Code (Jense, 2009; Salokorpi and Rytkönen, 2010). The ISM Code is based on very loosely written general principles and objectives. The rationale for that approach was that the Code could easily be applied in different shipping companies and ships that sail in highly varying conditions (IMO, 1993). However, the Code has been criticised to be fuzzy and a compromise between efficiency and accuracy (Jense, 2009). The Code does not give satisfactory information on how to implement a proper safety management system in a company (Jense, 2009; Lappalainen, 2016). Further, Jense criticises that the Code does not define the requirements for safety organisation in a company. The general level of the Code has caused it to be interpreted differently in different Flag States, and the Code does not provide enough support for consistent interpretations (Salokorpi and Rytkönen, 2010). The lack of information and guidance for proper implementation has also been reported by Lappalainen (2016). The interviewees of his study, too, would like to receive guidance for the implementation of a safety management system and recommendations for best practices.

In addition, the Code was established hastily as a quick response to the serious accidents, which has hampered implementation in the early days of the Code and also during recent years (Jense, 2009; Salokorpi and Rytkönen, 2010).

Seemingly, the ISM Code needs major revision in order to respond to current challenges. Unfortunately, it seems that there is not much interest in the revision among the major member states of the IMO. (Interview AU, 18.10.2016).

The situation in road transportation is quite different from that in other transport modes. There are no mandatory requirements for implementing safety management systems for road transportation organisations (Silla and Luoma, 2014). However, in Finland for example, some important elements of safety management need to be taken into account in road transportation companies based on the Occupational Safety and Health Act and the Act on the Transport of Dangerous Goods (Ojala, 2013). For example, according to the Occupational Safety and Health Act, employers are responsible for managing all risks related to work (Act, 738/2002). 
According to Hämäläinen and Heikkilä (2013), for example in Finland, not many road transportation companies have implemented any specific safety management systems yet (see also Kultalahti, 2015). However, in some companies safety issues have been incorporated in other management systems based on, for example, international quality management or environmental management standards (Hämäläinen and Heikkilä, 2013). In Sweden, the Swedish Association of Road Transport Companies has developed a specific standard for road traffic (Road Traffic Safety standard (RTS); Johansson 2011). The RTS standard is based on the ISO 9001 Quality Management System and the ISO 14001 Environment Management System. More than 100 road transport companies have implemented their safety management systems based on the RTS standard in Sweden since 2003 (Johansson, 2011). According to Silla and Luoma (2014), the reasons for implementing safety management systems are improved reliability of operations, better company image, various marketing reasons and meeting customer requirements.

The Finnish Transport Safety Agency has developed a responsibility model for road transport companies. The responsibility model aims to improve safety and environmentally sustainable practices in commercial transport. The model is based on voluntary participation of organisations. The model seeks to cover the major safety, quality and environmental issues relevant to road transport. The fundamental principle in developing the model has been that it could be applied in different types of companies. Particularly, the model is targeted to smaller companies by providing sample forms and instruction documents that make it easy to implement. (Nykänen and Karhula, 2015) The SMS Wheel developed by the European Railway Agency as well as international safety, quality and environmental management standards have been utilised for developing the responsibility model (Liimatainen et al., 2014). In addition, several national or local standards have been taken into account, such as the London Fleet Operator Recognition Scheme (FORS) (Liimatainen et al., 2014). FORS is a voluntary programme for transportation companies. FORS aims to promote safe, sustainable and environmentally friendly road transportation (Liimatainen, 2014).

Australia has introduced a voluntary safety management system for road transportation, called the National Heavy Vehicle Accreditation Scheme (NHVAS) (Walker, 2014). NHVAS provides a formal process for recognising operators who have robust safety and other management systems in place. NHVAS includes the following modules: Mass Management, Maintenance Management and Fatigue Management. Around $20 \%$ of the Australian truck fleet is enrolled in NHVAS. This represents approximately 7,200 operators with just over 90,000 vehicles (Walker, 2014).

It is difficult to estimate the number of users of the responsibility model, because there are no user certification or registration requirements (Kultalahti, 2015). As the model has only existed for a short time, some transportation companies may not yet be familiar with it (Kultalahti, 2015).

The International Standards Organisation has published a new Road Traffic Safety Management Systems Standard (ISO 39001) targeted to public and private organisations involved in road transport in 2012 (Silla and Luoma, 2014). As other ISO management system standards, ISO 39001 follows the principle of continuous improvement. It has a common structure comparable to the other ISO standards for management systems (Hämäläinen and Heikkilä, 2013; Silla and Luoma, 2014). ISO 39001 requires the development and implementation of an appropriate road traffic safety policy, development of road traffic safety objectives and action plans that take into account legal and other requirements to which the organisation subscribes, and information about elements and criteria related to road traffic safety that the organisation identifies as those which it can control and those which it can influence (Johansson, 2011; Hämäläinen and Heikkilä, 2013). The standard provides general principles for safety management but no specific descriptions of how an organisation should define its safety procedures (Silla and Luoma, 2014). The generic nature of the standard facilitates its applicability in a wide range of organisations (Silla and Luoma, 2014).

Safety management systems are not common in road transportation (Hämäläinen and Heikkilä, 2013; Kultalahti, 2015). One reason for that could be that the majority of road transportation companies are very small (Kultalahti, 2015; interview, SSt 21.11.2016). They may not have the necessary resources and competence for implementing a safety management system. In 
addition, the diversity of applicable standards may lead to hesitation in the companies (Kultalahti, 2015).

The situation in road transportation could indicate that safety management systems will not be implemented extensively among transportation companies without mandatory legislation. However, quality and environmental management systems are applied more widely among road transportation companies because of customer requirements. Hopefully, the charterers will put some pressure on the implementation of safety management systems as well.

ISO 39001 has existed for such a short time that not much experience has yet been gathered of its application. A Swedish road transport company, Närkefrakt, is probably the first company in the world certified according to the ISO 39001 standard (Swedish Association of Road Transport Companies, 2012). Therefore, it is too early to estimate the final success of the standard.

However, the ISO 39001 standard has already been criticised. The standard focuses too much on serious accidents and does not facilitate an integrated approach to safety management (interview, SSt 21.11.2016).

\subsection{Regulatory stumbling blocks}

In maritime industry the enforcement of safety management regulation has been studied extensively. One reason for this is that safety management systems based on mandatory legislation have been employed for a long time in the maritime industry. Another reason is that several problems and difficulties have appeared in the implementation of safety management regulation due to the special characteristics of international shipping caused by geographical factors (Lappalainen, 2016).

The safety regulations for shipping work at several geographical levels (Kuronen and Tapaninen, 2009; van Leeuwen, 2015). At the international level, the most important actor is the IMO. The major regulatory instrument regarding maritime safety is the International Convention for the Safety of Life at Sea (SOLAS), which also includes the requirement for implementing safety management systems. According to Stopford (cited in Kuronen and Tapaninen, 2009), worldwide regulations on maritime safety are needed in order to avoid a situation where each coastal state would have its own rules on issues such as ship structure, manning etc.

In Europe, the European Union provides safety regulation at regional level (Kuronen and Tapaninen, 2009). For example, compliance with the ISM Code was made compulsory on Ro-Ro passenger ships in EU's internal traffic by a Council Regulation from the beginning of July 1996 (Vepsäläinen and Lappalainen, 2010). As stated above, safety management regulation is implemented at national level, i.e. by the flag states (Kuronen and Tapaninen, 2009; YliskyläPeuralahti and Gritsenko, 2014).

The current multi-level maritime safety regime has been criticised as being ineffective in ensuring that every ship complies with the international maritime regulations (Roe, 2009; Kuronen and Tapaninen, 2009; Fan et al., 2014; Rodríguez and Piniella, 2014; Cariou and Wolff, 2015). The current safety regime allows sub-standard shipping because some flag states (Flags of Convenience; FOC) permit foreign ships to be registered in their open registers which are more permissive regarding, for example, safety regulation and manning requirements (Bhattacharya and Tang, 2013; Fan et al., 2014; Rodríguez and Piniella, 2014; Cariou and Wolff, 2015).

According to Lappalainen et al. (2013), the implementation of international legislation is based on flag states, and flag states have very different standards for implementing regulations. According to Knudsen and Hassler (2011), there are inconsistencies and 'conflicts' concerning the inspection practices, interpretation of rules and implementation strategies between flag states. This enables unfair competition in the shipping business.

One important reason for registering ships in a flag of convenience is that the FOCs allow multinational crews, thus allowing the shipping companies to reduce their manning costs (Theotokas and Progoulaki, 2007; Bhattacharya and Tang, 2013; Fan et al., 2014). Several studies have shown 
that the nationality of crew members plays a significant role in safety (Horck, 2010; Baylon and Santos, 2011, Berg et al., 2013) and it has been indicated that the implementation of safety management is more difficult with a multinational crew (Mårtensson, 2006; Theotokas and Progoulaki, 2007). Communication problems based on poor language skills and different cultural assumptions, for example, may hamper the implementation of safety management systems (Sampson and Zhao, 2003; Pyne and Koester, 2005; Hetherington et al., 2006; Håvold, 2007; Popescu et al., 2010).

The operation of sub-standard ships is also made possible by the failure of the flag-state control system to supervise ship conditions in a uniform way in all flag states. Several ship inspection systems have been established to fill the gaps in the enforcement of the maritime safety regime at international and national level and to verify the actual conditions on the ship (Kuronen and Tapaninen, 2010; Fan et al., 2014; van Leeuwen, 2015). There are several ship inspection systems besides flag sate control: port state control systems, supervision performed by classification societies, and vetting inspections carried out by major oil companies.

Port State Control plays a central role in controlling the implementation of the ISM Code. In Europe, the Port State Control system was agreed upon in the Paris Memorandum of Understanding on Port State Control (Paris MoU) in Paris in 1982. It is indicated that Port State Control inspections have been effective in improving maritime safety by reducing deficiencies related to international safety standards (Cariou et al., 2008) and have hence reduced the probability of casualties (Knapp and Franses, 2007; Heij et al., 2011).

However, several authors have found problems in the various inspection systems (Knapp and Franses, 2007; Kuronen and Tapaninen, 2010; Lappalainen et al., 2013; Ravira and Piniella, 2016). Lappalainen et al. (2013) have revealed criticism among maritime personnel due to overlapping inspections and incompatibilities in the work of inspecting officers. The various inspection systems do not recognise inspections performed by another regime (Kuronen and Tapaninen, 2010). What is more, there does not seem to be significant differences between various inspections, which increase the workload on the ships and add to the costs. (Knapp and Franses 2007). There is a great concern about the added value for safety of the various inspection systems (Lappalainen et al., 2013).

Lappalainen et al. (2012) evaluated the implementation of the ISM Code in the Finnish maritime industry. They found that there are several deficiencies in the ISM audits carried out by the flag state. The audits were carried out differently depending on the personal skill of the maritime inspectors. It was found that the inspectors tended to interpret the requirements of the ISM Code differently. Similarly, Lappalainen et al. (2013) found problems with port state control inspections. There were inconsistencies and 'conflicts' in the inspection practices and interpretation of rules between the port states (Lappalainen et al., 2013). Ravira and Piniella (2016) assessed the impact of port state control inspectors' professional profile on inspection results. They found that "all inspectors will be better equipped to evaluate some types of deficiency more than others according to their individual academic training and experience on ships" (Ravira and Piniella, 2016). Ravira and Piniella (2016) think that multidisciplinary teams are needed for carrying out the port state control inspections.

In addition to excessive inspections, the shipping industry suffers from problems of regulatory overload (Lappalainen et al., 2013). Lappalainen et al. (2013) found that the regulatory burden is quite heavy as regards safety management in shipping. Their study showed that the content and implementation of the current regulations should be improved instead of preparing new regulations. For the most part, the current regulations already include and regulate all necessary issues. Maritime safety cannot be ensured by increasing the amount of regulation, by adding control and inspections or by creating specific certificates for every purpose. In addition, Bhattacharya and Tang (2013) claimed that the geographical distance between ships and regulators further complicates the surveillance of safety standards.

Similar problems regarding various inspections and overlapping audits can be found in aviation (Mills, 2016). According to Mills (2016), during the late 1990s, airline companies were subjected to a great number of safety audits carried out by safety regulators, airline alliances and 
other organisations using inconsistent standards and practices. The airline companies were wasting significant resources on audits that could not be generalised to other areas and therefore prevented the sharing of results with other carriers. The overlapping and redundant audits cost a lot of money to the airlines (Mills, 2016). The different audit programs were not accepted and recognised by other stakeholders. In order to eliminate the need for redundant or duplicated audits, IATA designed a sharing system for audit findings that allowed interested parties to view an airline's audit results (Mills, 2016). The IATA Operational Safety Audit (IOSA) project was launched in February 2001. The IOSA program will be presented more thoroughly in section 3 .

\subsection{Regulation or self-regulation}

Self-regulation has been proposed to tackle the problems in the governance of maritime safety (Lappalainen et al., 2013). In their study among maritime personnel, it was found that voluntary activities by companies were strongly supported. Effective self-regulation has many advantages compared to governmental regulation. For instance, it is more sensitive to varying situations, can adapt to changes more quickly and reduces public expenditure (Lappalainen et al., 2013).

According to Grote (2012), there is a trend to move away from prescriptive regulation towards goal-oriented legislation, which promotes self-regulation. This provides companies freedom to proactively manage safety in the best suitable way. According to Grote (2012), the move towards goal-oriented legislation and self-regulation represents a new safety approach called resilience, which means that uncertainty should be coped with instead of managing it away. From the point of view of safety management, companies do not need to react to changes in external demands and adapt their safety management accordingly. They do not have to be ready for external audits and inspections at any time (Grote, 2012). To a large extent, companies have to find out themselves what kind of safety management best fits their particular situation and be more proactive in monitoring their safety performance (Grote, 2012).

The transition from regulation to self-regulation requires that the authorities adopt a more consultative role, which will require different competencies of regulators (Grote, 2012). The companies need support and practical guidance in the implementation of safety management systems (Reiman et al., 2012; Lappalainen, 2016). The authorities should have a more developmentoriented approach and encourage the companies to continuous improvement (Lappalainen et al., 2011). According to Reiman et al. (21012), aviation authorities should produce information and guidance for interpreting safety management regulations. The ICAO Safety Management Manual is a rather detailed description about implementing safety management systems (Reiman et al., 2012).

In order to facilitate the implementation of safety management systems, the European Aviation Safety Agency (EASA), the United States Federal Aviation Administration (FAA) and Transport Canada Civil Aviation (TCCA) have founded the Safety Management International Collaboration Group (SM ICG). The purpose of SM ICG is to promote a common understanding of safety management and Safety Management System (SMS)/State Safety Program (SSP) principles and requirements (SM ICG, 2010). Another example in aviation is the European Commercial Aviation Safety Team (ECAST). ECAST, the Commercial Air Transport component of the European Strategic Safety Initiative (ESSI) has published material for organisations that need to implement a Safety Management System (SMS). The objective is to promote best practices and support industry implementation of European and international regulatory provisions (EASA, 2016).

The European Railway Agency has set up a Human Factors network for promoting the dialogue between railway stakeholders about the systematic integration of a human-centred perspective through the implementation of Safety Management Systems (ERA, 2016).

According to Walker (2014), research on self-regulation shows that its success relies on partnership between the industry and government agencies. Besides the support and encouragement from administration, co-operation between companies is also needed in order to promote selfregulation (Lappalainen et al., 2013). That issue will be elaborated in section 3. 


\subsection{Safety culture as a prerequisite of safety management}

Reiman et al. (2012) have reviewed the studies about safety culture in different modes of transport. They found that those studies are rare which deal with more than one transport mode at a time (Reiman, et al., 2012). One example is Ek et al. (2007, quoted in Reiman et al., 2012), who studied safety culture in maritime transportation and aviation. Ek found that both in aviation and in shipping, managers considered the safety culture to be at a higher level than the staff members did (Ek et al., 2007, quoted in Reiman et al., 2012). Any studies that would have compared the safety cultures between different transport modes could not be found (Reiman, et al., 2012).

The origin of the concept of safety culture can be dated to the second half of the 1980's after several fatal accidents, for example the Chernobyl nuclear power station accident in 1986, the falling of the oil production platform Piper Alpha in 1988 and the disaster of the space shuttle Challenger in January of 1986 (Reiman and Oedewald, 2007; Guldenmund, 2010; Antonsen, 2012; Strauch, 2015; Warszawska and Kraslawski, 2015). As a response, the authorities soon began to demand a proper safety culture, first in the nuclear power industry and then in other safety critical fields (Reiman and Oedewald, 2007). In the shipping industry, the concept of safety culture emerged after the capsising of Herald of Free Enterprise in March of 1987 (Goulielmos, 2001; Anderson, 2003; Gill and Wahner, 2012). A breakdown in the organisation safety culture was seen as the main contributor to these accidents (Gill and Wahner, 2012; Antonsen, 2012; Strauch, 2015; Warszawska and Kraslawski, 2015).

The concept of safety culture was adopted to safety studies from the organisational culture theory (Lappalainen, 2016). The organisational culture theory includes a promise that if the prevailing cultural features of the organisation are taken into consideration, the company productivity and financial performance can be enhanced (Barley and Kunda, 1992). This promise has gone furthest in the movement of total quality management (TQM) (Guldenmund, 2010). The TQM movement believes that strong commitment to the company culture directly supports the quality objectives and high productivity. The basic principles of TQM are the willingness to seek continuous improvement, sustained learning and a strive to develop the operations.

Consequently, it was strongly believed that safety culture could be created by implementing a safety management system in an organisation (Antonsen, 2012; Lappalainen, 2016). The safety management systems presume that an ideal safety culture should include some specific features (Antonsen, 2012; Reiman et al., 2012; Lappalainen, 2016). Reiman et al. (2012) have identified six dimensions of a good safety culture:

- Safety is a genuine value, taken into account in decision making and daily operations.

- Safety is understood as a systemic and complex phenomenon.

- Hazards and requirements of the core operations are thoroughly understood.

- The organisation is conscious about uncertainties and alert towards possible risks.

- Responsibility is taken for the safe functioning of the entire system.

- Operations are organised in a manageable way, activities are properly performed and the system is manageable.

In the ISM Code, these features of safety culture are stated as follows (Lappalainen, 2016):

- The cornerstone of good safety management is commitment from the top. In matters of safety and pollution prevention it is the commitment, competence, attitudes and motivation of individuals at all levels that determines the end result.

- Understanding that accidents are preventable through following correct procedures and establishing best practice.

- Constantly thinking of safety.

- Seeking continuous improvement.

Guldenmund (2010) has noted that the TQM ideology in the arena of safety culture displays somewhat religious features, considering the strong and uncritical belief that by adopting a particular safety-related frame of reference and performing particular activities, a total safety culture (TSC) 
can be achieved (see also Vu and De Chieri, 2014). This approach to safety culture has been criticised to be one-sided (Lappalainen, 2016) and far from unproblematic (Antonsen, 2012). Antonsen (2012) warns that these features or qualities of safety culture are not based on a solid empirical basis but on organisational dimensions that are the easiest to measure and monitor. What is more, Antonsen (2012) suspects that the safety culture approach is based on the belief that a culture can be easily modified and engineered in order to improve safety in a high-risk organisation. In the literature on organisational culture, this approach is commonly defined as a functionalist approach or perspective towards culture (Lappalainen, 2016).

However, safety culture should be approached from other theoretical perspectives of organisational culture as well (Lappalainen, 2016). Other perspectives of organisational culture can enhance the understanding about safety culture (Lappalainen, 2016) and provide "greater depth and practical applicability of safety culture" (Edwards et al., 2013).

The organisational culture can be defined as a background factor influencing the company's operations, an organisational variable or a metaphor for conceptualising the organisation (Smircich, 1983). Most definitions consider safety culture as a part of organisational culture, with a focus on safety (Glendon and Stanton, 2000; Wiegmann et al., 2002; Richter and Koch, 2004; Reiman et al., 2008: Guldenmund, 2014). Respectively, safety climate is defined as the employees' shared perceptions about their working environment in relation to safety (see, for example, Zohar, 2010; Kines et al., 2011; Hystad et al., 2013b; Schwatka et al., 2016).

According to $\mathrm{Vu}$ and De Chieri (2014) there is no consensus about the definition and the features of safety culture and safety climate (see also Antonsen, 2012). However, Vu and De Chieri (2014) have found that it is broadly agreed that "safety culture is a subset of organisational culture that is unconscious, invisible and characterised by shared underlying values and attitudes towards safety" (see also, Lofquist et al., 2017. It is also commonly agreed that the safety climate is a manifestation of safety culture, which is observable and close to the surface (Oltedal, 2011; Vu and De Chieri, 2014; Schwatka et al., 2016).

According to Vu and De Chieri (2014), the theoretical basis for safety culture that has been most commonly adopted is Schein's model of organisational culture. In that model the structure of organisational culture is usually described as a system with different levels, from the more superficial aspects to the deeper layers that are most commonly divided in three levels (Schein, 1992; Guldenmund, 2010; Vu and De Chieri, 2014). The surface level of organisational culture includes, among other things, the visible behaviour and established behavioural norms. By observing the artefacts and creations, for example, visible behaviour can be described, but not the reasons behind the behaviour. At the intermediate level are the attitudes and perceptions that cannot be directly observed, but can be inferred from visible behaviour or can be accessed through interviews and enquiries, for example. At the deepest level are the core values or basic assumptions that are difficult to recognise and assess. (Lappalainen, 2016)

The theoretical debate about different perspectives or traditions of organisational culture deals with the question whether the basic assumptions are changeable and measurable (Lappalainen, 2016). The theories of organisational culture can be classified in several ways. According to some authors, there are three major traditions (McAuley et al., 2007) or paradigms (Guldenmund, 2014) when it comes to approaching the concept of organisation culture: the functionalist, the interpretive and the postmodernist approach, which is called constructivism by Guldenmund (Schultz and Hatch, 1996; McAuley et al., 2007; Demers 2007; Guldenmund, 2014).

The functional tradition is based on the belief that organisational culture is built into the organisation as a subsystem, in the same way as organisational structure, and its purpose is to advance the development of organisational goals and values as defined by the management of the organisation (McAuley et al., 2007; Guldenmund, 2010). The following common conceptions can be linked to the functional safety culture theory (source: Lappalainen, 2016):

- There is an ideal state that the organisation should aspire to (Reiman et al., 2008).

- The management has a great influence on enhancing safety (Richter and Koch, 2004). 
- Top-down control (Richter and Koch, 2004).

- The culture can be changed and manipulated (Richter and Koch, 2004; Reiman et al., 2008).

- Safety culture enhances the organisation's operating ability (Reiman et al., 2008).

- Adopting a safety culture reduces human errors (Rothblum et al., 2002).

The functional theory implies that the culture exists on a continuum, and when it comes to safety culture, an organisation can have either a good or a poor safety culture (Wiegmann et al., 2002; see also Pidgeon, 1998; Guldenmund, 2010; Lützhöft et al., 2011). Interpretive approaches assume that the organisational culture is a system of shared symbols and meanings, and serves as a means for all members of an organisation to interpret their collective identity, beliefs and behaviours (Smircich, 1983; Allaire and Fisirotu, 1984; Glendon and Stanton, 2000; McAuley et al., 2007). The most prominent difference between the functional and interpretive theories is how much the management is considered to be able to control, change or manipulate the organisational culture. In the interpretive approach, culture is a factor in the organisation that people have to adapt to, and which is difficult, if not impossible to change. In that case, the management has limited power to mend and improve unwanted cultural factors or create a new culture to replace the old one. The management efforts to promote their objectives are prevented by the inflexible culture (Smircich, 1983). The culture develops slowly over time, even undetected.

The third approach is called postmodernism (Schultz and Hatch, 1996; McAuley et al., 2007; Demers, 2007) or social constructivism (Guldenmund, 2014). The postmodern approach challenges both functionalist and interpretive approaches. Both approaches look for unity and homogenisation of the people in the organisation in order to create an efficient and effective organisation. According to Alvesson (2002), this viewpoint is based on the causal idea that creating the right organisational culture can be expected to induce considerable and important results and effects in the organisation, such as loyalty, reliability, enhanced productivity and enhanced safety. This viewpoint has also been criticised because it is narrowly based on the viewpoints and understandings of the elite or management (Alvesson, 2002; Martin, 2007; Haukelid, 2008; Guldenmund, 2014). It is assumed that the organisation and its employees have corresponding, rational goals as long as they are understood correctly at all levels of the organisation. Alvesson (2002) calls the approach that aims for a unified organisational culture "integration". This is a very top-down management view of cultural formation that underplays the diversity of cultural forms in an organisation.

The postmodernists assume that an organisational culture is more often rather differentiated and fragmented than in harmony and based on shared common values and norms (Haukelid, 2008; Schultz and Hatch. 1998; Knights, 2002; Guldenmund, 2014). Conflicts between different groups and subcultures can emerge. Cultural manifestations are rarely in a neat order; the order of the values varies and the cultural ideas are unsystematic and inconsistent. Thus the organisational culture tends to be more or less fragmented (Alvesson, 2002; Lappalainen, 2016).

By examining the air traffic management (ATM) industry in Europe, Reader et al. (2015) found that there were significant differences between management and operational personnel hoe they assess safety culture. Also, Lofquist et al. (2017) found differences between management culture, engineering culture and operations culture. According to Lofquist et al. (2017) management, engineers and operators make sense of artefacts, e.g. safety rules and routines, in different ways. They claim that the differences of management culture, engineering culture and operations culture manifest in differences in complying with all the safety rules (Lofquist et al., 2017).

Grote (2012) has argued that organisational culture and safety culture cannot be managed or prescribed. According to Grote (2012), culture is affected through safety management measures in the same way as other features of the organisation, but it cannot be managed as such. Culture cannot be prescribed by any attempts of a regulator either (Grote, 2012). Therefore, instead of prescribing and regulating safety culture, the organisations and regulators should carefully consider the basic assumptions which could be cultural enablers or cultural barriers for safety performance in an organisation (Alvesson, 2002; Grote, 2012; Lappalainen, 2016). According to Grote (2012), organisations should "be alert to any indication of cultural norms and assumptions being a source of resistance to change towards more safety and work on those norms and assumptions accordingly." 
However, according to Grote (2012), there can be good and bad safety cultures in relation to an organisations' basic assumptions, but there is no single truth about what kind of safety culture would be the best (Lappalainen, 2016). The differentiation, fragmentation and inconsistency of organisational culture should be taken into account when developing the safety culture (Alvesson, 2002; Lappalainen, 2016). In order to understand the multiple perspectives of safety culture more comprehensively, multiple theoretical perspectives and methodological approaches are needed. Applying diverse theoretical perspectives will yield a more comprehensive picture on safety culture and thus provide significant help for the implementation of safety management systems. This is supported by Lofquist et al. (2017). They argue that looking at the safety culture as only one, overarching culture, could result in shortcomings in understanding the true nature of the safety culture (Lofquist et al., 2017). Lofquist et al. (2017) propose that the sub-cultures' sense-making should be explored across different levels in order to get insight into the underlying logics of the dynamics in the organisation. Lofquist et al. (2017) trust that by understanding the different safety sub-cultures' sensemaking the differences in complying with the safety rules would be better understood.

As stated above, it is commonly understood that features of safety culture pre-determine the success of the implementation of safety management systems. The culture of an organisation can be differentiated and fragmented. For example, the staff can have a totally different approach towards safety than the generic safety management regime presumes. In section 4 the discussion continues about how those different approaches may hinder the successful implementation of safety management systems.

\subsection{Summary}

In aviation, rail and maritime transportation, the implementation of safety management systems has been based on mandatory legislation. In road transportation, safety management systems are voluntary but not applied extensively among transportation companies. It seems that some mandatory regulation is needed in order to engage the companies to safety management practises more extensively. In shipping, the ISM Code has not progressed much after its origin in the early 90's. The need for further development has been recognised, but the member states of IMO have not taken an initiative for that. The newly revised European Railway Safety Directive provides a positive example on the development of safety management standards. The Directive follows the general structure of ISO management standards, and a human factor element is also included in the Directive.

Particularly, the shipping industry has suffered from a high regulatory burden due to excessive rules and inspections. Self-regulatory approaches are needed to tackle these problems. However, some form of government regulation is needed to make self-regulation effective. Regulatory agencies play a vital role in providing supporting infrastructures for self-regulation and in monitoring the outcomes of self-regulation. Self-regulation also requires co-operation between operators and some maturity in the industry in order to be effective. This issue will be further discussed in the next section.

The concept of safety culture should be understood more comprehensively. The transition to self-regulation could also give more freedom to local approaches to safety culture. This issue will be dealt with more thoroughly in section 4 . 


\section{SMS obstacles for operators}

This section discusses the difficulties and problems for organisations in implementing safety management systems.

Almost all studies related to safety management have emphasised the importance of management commitment for the successful implementation of safety management systems. Thus the starting point for this section is to discuss this issue.

Second, this section reviews the external factors that may cause additional challenges for organisations in implementing safety management systems. For example in maritime industry, geographic factors seem to be more influential than in other transport modes. The competitive nature of the industry may also pose extra challenges.

Third, this section discusses how the issue of workforce multiculturalism may hinder the instillation of safety culture among the staff.

Fourth, this section deals with the issue of resources and competence available to operators.

Fifth, this section introduces some promising examples of co-operation between operators as one possible solution to the obstacles of implementing safety management systems.

\subsection{Management commitment}

The commitment of the top management is recognised as playing a critical role in implementing safety management systems (Reason, 1997; Wiegmann et al., 2002). Poor management commitment has been found as a contributing factor in several very serious accidents.

The management is responsible for defining a company's safety policy, making adequate resources and tools available for the staff to ensure that the safety policy can be realised, and setting realistic and achievable targets for required safety performance. In addition, the management is responsible for ensuring that the safety policy becomes visible and the safety targets are achieved (Wiegmann et al., 2002; Lappalainen, 2008).

Studies have indicated both positive and critical reflections on management commitment (see, for example, Bhattacharya, 2009; Lappalainen, 2016). The management of shipping companies have demonstrated their commitment better and better in the course of time, which has been manifested in the provision of resources and funds for safety investments and crew safety training. In addition, some studies have indicated that the management has taken a visible role regarding safety. However, the management has also been criticised for similar reasons; they have rejected safety investments or been passive with regard to safety.

Studies have found quite simple ways for the management to promote commitment to safety. The management should actively demonstrate its commitment by showing a visible positive attitude towards safety and actively promoting safety. The management should encourage and lead the staff with their own example and by communicating openly with the staff about safety related issues. The management should be present and actively involved in, for example, safety training and internal events such as meeting and seminars (Collins and Gadd, 2002). In maritime transport, it has been found that paying regular visits on-board is an effective way to demonstrate commitment by management (Bhattacharya, 2009; Lappalainen, 2016).

\subsection{External factors affecting the implementation of SMS}

In addition to the regulatory and cultural difficulties presented in section 2, there are other external determinants that may make it more difficult to implement safety management systems in some modes of transportation. Maritime transportation has been taken as an example because there the external factors seem to have a stronger effect than in other transport modes (Roe, 2016). 
The spatial features of an industry strongly affect the shape and structure of an organisation. Shipping in particular is an industry where organisational and geographical features are intertwined. The characteristics of organisations in shipping companies and on board ships are influenced by geography, i.e. distance, mobility, nationality etc. (Lappalainen, 2016). Shipping is characterised as "Management from a Distance" (Goulielmos and Gatzoli, 2012).

There is always more or less distance between the ship and the office. That distance poses several problems in implementing safety management systems in shipping. It is indicated that the culture of a company can be different than the culture of its ships (Grabowski et al., 2007; Goulielmos and Gatzoli, 2012). The geographical distance between the ship owner and the ships forms a concrete barrier in developing a strong safety culture based on the shipping company's accepted goals and values. On the ships, the culture is strongly determined, but the ship master may cause a threat to safety on-board. A strict hierarchical order on-board kept by an autocratic master could be a risk in a hazardous situation. On the other hand, if decision-making is too centralised to the shore management and if the shipmaster's decision-making power is limited, the requirements of the safety management system could be compromised (Xue at al. 2015). What is more, shipmasters are obliged to work under a strong commercial pressure (Goulielmos and Gatzoli, 2012) caused by the shore management, e.g. by ordering them to keep the sailing schedules (Xue at al. 2015).

The distance between the ship owner and the ship's personnel, as well as the fragmented organisational structure, may cause the safety engagement level of employees among ship crews to be lower than in shore-based industries (Bhattacharya, 2015). The personnel on-board have minimal or no contact with the ship owners because of the geographical and organisational distance; the owner, the ships, the ship operator and the ships' personnel may all come from different countries. Bhattacharya (2015) has found this problematic, because it is indicated that employee engagement correlates with the safety level.

Yliskylä-Peuralahti and Gritsenko (2014) have concluded that "there are multiple geographies in place where shipping is practised". The shipping company may be located in one country, their ships can be registered in another country, the crew members may represent multiple nationalities, and the ships can operate to and from multiple locations all over the world (Berg et al., 2013; Bhattacharya and Tang, 2013; Walters and Bailey, 2013; Bhattacharya, Y. 2015; Yliskylä-Peuralahti and Gritsenko, 2014). According to Roe (2016), "the international shipping industry is in many ways the finest example of the development of globalisation that can be found". In shipping the competition is fierce. The geographical and competitive nature of the shipping business makes the implementation of safety management systems very challenging.

It is indicated that the implementation of a safety management system is much easier in a closed or simple business environment (Lappalainen, 2016). Traditionally the ship owners have hired their staff directly, and the staff has usually represented the same nationality as the owners. In addition, the ships have sailed under the flag of the owner's nation. However, due to the globalisation and harsh competition, the shipping industry is under constant transition towards a more and more fragmented business environment (Lappalainen, 2016; Roe, 2016). Flagging ships out to FOC countries, using manning agencies for hiring personnel and outsourcing ship management are growing trends in the shipping business. However, the overall responsibility for safety remains with a single company in the safety management standards. It is a topical question how a single company can, for example, promote safety culture in a fragmented and globalised business environment.

It seems that multiple geographies do not have as much influence in the other transport modes (Roe, 2016). However, the situation in the international airline industry is comparable to that in international shipping.

According to Maurino (2016), aviation organisations are widely spread geographically. In addition to airline companies, those organisations whose business operations are "anchored" to the ground also operate at a global level. For example the Approved Maintenance Organisations (AMOs), while 
physically located in one country, maintain aircraft operated by airlines from all over the world. Similarly, the Approved Training Organisations (ATOs) which are physically located in one country are training pilots from all over the world.

The aviation industry is also highly competitive. For example in Europe, the liberalisation of air transportation in the 1990's has led to the emergence and growth of what have become known as lowcost airlines (Delaplace, and Dobruszkes, 2015; Mason et al., 2016). Many of these airlines are literally "virtual", meaning that they do not own the airplanes but lease them, and they subcontract training and maintenance as well as all support services (Maurino, 2016).

Similarly, liberalisation has started in European rail transportation. Rail transportation is undergoing transition to more open European-wide markets, where the transport companies can operate in other countries within the EU area and hire their personnel freely from other EU member states(Alexandersson, and Rigas, 2013; Beria et al., 2012; Pellegrini, and Rodriguez, 2013). Railway legislation is based on a distinction between infrastructure managers who run the network and railway companies who use it for transporting passengers or goods (Beria et al., 2012). Different organisational entities must be set up for transport operations on the one hand and infrastructure management on the other. The market for international rail passenger services has been liberalised in the EU since 1 January 2010 (Beria et al., 2012). However, the actual level of market opening is still limited, and the liberalisation has actually proceeded only in some cases (Beria et al., 2012; Pellegrini, and Rodriguez, 2013). In fact, there is only one large railway operator in many European countries operating in a sort of monopoly (Pellegrini, and Rodriguez, 2013).

Consequently, the liberalisation of rail transportation has raised worries about safety (Braut et al., 2014). However, the research results are contradictory (Braut et al., 2014). Evans (2007, 2010 and 2013) who studied the impact of liberalisation and privatisation in several countries found no support for a decline in safety level based on accident statistics. In contrast to that, Jupe and Crompton (2006) have claimed that liberalisation and privatisation in rail transportation in Britain has contributed to fatal accidents. According to Jupe and Crompton (2006), the liberalisation and privatisation led to a fragmentation of the industry in the late 1990's. Further, the industry fragmentation led to a neglect of safety issues between organisational boundaries, which contributed to three major fatal accidents between 1997 and 2000 (Jupe and Crompton, 2006). Before privatisation, the British Rail had been staffed by an integrated workforce, which developed a culture "in which safety was nurtured as a habit of thought". According to Jupe and Crompton (2006), this safety culture was splintered and weakened. The fragmentation of the industry had led to coordination problems between the infrastructure manager, the railway undertakings and the subcontractors (Jupe and Crompton, 2006). For example, the reporting of faults had failed due to a lack of coordination between organisations (Jupe and Crompton, 2006),

One solution for overcoming the problems posed by the fragmented business environment would be promoting co-operation and networking between the operators. Some promising examples of industrial co-operation are introduced in sub-section 3.4.

\subsection{Multinational crews and the transitive nature of workforce}

As stated above in sub-section 3.2, shipping is an extremely globalised business. In order to reduce manning costs the ship owners have employed crews from countries where labour costs are low (Theotokas and Progoulaki, 2007). This has resulted in multicultural and multilingual crews on-board. According to Theotokas and Progoulaki (2007), $80 \%$ of the world merchant fleet is manned by multicultural and multilingual crews.

Several studies have shown that the nationality of the crew members plays a significant role in relation to safety (Berg et al., 2013), and it has been claimed that multicultural crews are a risk for maritime safety (Theotokas and Progoulaki, 2007). Communication problems based on poor language skills, for example, are identified as one important risk factor (Hetherington et al., 2006). The 
multinational workplace is characterised by rare social contacts and interactions between different nationality groups, which might cause conflicts and communication problems (Theotokas and Progoulaki, 2007).

Noort et al (2015) examined the relationship between safety culture and national culture among air traffic management employees in 21 European countries. They found that employees' safety-related attitudes and practices were influenced by their national culture, and thus by factors outside the direct control of organisational management (Noort et al., 2015). Also Reader et al., (2015) found that national culture has considerable implications for how safety culture is conceptualised and understood. Based on their study among Air Traffic Management employees in Europe, they claim that generic safety culture models cannot automatically be applied from one cultural setting to another, and may require substantial customisation (Reader et al., 2015). In Europe, national air navigation service providers operate in a single interconnected industry, and their personnel are primarily nationals of the host country, with practices being influenced by both European-wide standards and organisational characteristics (Reader et al., 2015).

Strauch (2010) has studied cultural differences and their effects on sociotechnical system operations in commercial air transportation. According to Strauch (2010), the aviation system involves intercultural interactions. Typically, such interactions occur when pilots fly to countries different from their own. Multinational cockpit crews are relatively uncommon in the world's commercial fleet, although they are present in some airlines. Strauch (2010) found that under certain conditions, cultural differences can lead to accidents in complex sociotechnical systems. "National differences in thinking and reasoning styles can create formidable barriers to understanding and collaboration" and lead to errors among culturally heterogeneous teams (Strauch, 2010). What is more, culturally homogeneous teams have been found to be more successful than heterogeneous teams in problem solving tasks (Strauch, 2010). In cases where the heterogeneous teams have worked together for a longer period, the differences in problem-solving have decreased.

Alongside with multinational crews, the shipping industry is characterised by a high turnover of workforce. It is indicated that the crew members do not get the necessary feeling of "ownership" of their ship and do not have enough time to assimilate all relevant safety issues. High employee turnover can lead to a lower level of employee engagement (Wachter and Yorio, 2014). According to Raines (2011), employee engagement has a strong correlation with safety performance.

It is evident that multinational crews and a high turnover of staff make it more challenging for the operators to instil the safety culture among their staff. Therefore, training in understanding other cultures is needed (Theotokas and Progoulaki, 2007; Berg et al., 2013). It is indicated that culture management can enhance crew team cohesion, upgrade communication at all levels and, finally, improve safety (Theotokas and Progoulaki, 2007)

\subsection{Lack of resources and competence}

Particularly in shipping and in road transportation, most operators are small or medium-sized companies. However, the requirements for safety management are similar in smaller companies as in large companies. What is more, the requirements for implementing safety management systems are extensive (Almklov et al., 2016).

It is indicated that in many small and medium-sized companies there is a lack of knowledge and expertise in implementing safety management systems (Bhattacharya, 2009; Almklov et al., 2016). In addition, in many shipping companies the implementation of safety management is embodied in the DPAs (Lappalainen, 2016).

Almklov et al. (2016) have concluded that many companies need help in interpreting the abstract and generic requirements of safety management standards and in bringing them into practise in order to satisfy the authorities. The companies have become increasingly dependent on external consultants 
to transform the regulations into practice and help them to develop a safety management system (Almklov et al., 2016). This trend has been considered problematic, because the interests of external consultants may not be similar to those of the companies and the cost of the consultants can be high (Almklov et al., 2016). Another concern is that the safety management systems implemented by external consultants may lead to disempowerment of the companies themselves and their own perspectives. This issue will be discussed further in the next section.

\subsection{Co-operation between operators}

As discussed above in section 2, there has been a transition from regulation to self-regulation in all transport modes. The regulatory agencies play a vital role in providing supporting infrastructures for self-regulation and in monitoring its outcomes. Besides the support and encouragement from administrative bodies, co-operation between companies is also needed to promote self-regulation (Lappalainen et al., 2013).

Recent examples of industry self-regulation and co-operation can be found in the maritime industry. One of the major energy companies, Shell, has introduced a partnership programme for promoting safety culture among its maritime partners by organising annual safety workshops (Lloyds List, November 2016). Some 500 of Shell's partners including ship owners, supply boat operators, charterers etc. have participated in the network (Lloyds List, November 2016).

Another example on industry self-regulation is the Container Ship Safety Forum (CSSF) launched in 2014 (Lloyds List, November 2016). The CSSF is a global business-to-business network aiming to improve safety performance and management practices in the container shipping industry. In order to achieve this, CSSF members collaborate through measurement, reporting and benchmarking as well as sharing best practices (Lloyds List, November 2016). As of January 2016, the CSSF represents one third of the teu 1 capacity of the global container ship fleet. The Forum provides information about improvements in safety management systems, the development of common safety standards, key performance indicators, and risk assessments. It provides a network of peers to exchange best practices and discuss challenges in operational safety and compliance (CSSF, 2016)

Successful examples can also be found in aviation. As already mentioned in section 2, IATA has established an audit findings sharing system (IOSA) for airlines (Mills, 2016). Another self-regulatory initiative from IATA is the Safety Trend Evaluation, Analysis and Data Exchange System (STEADES) (Mills, 2016). STEADES and IOSA are private self-regulatory programs designed and implemented by the airline industry to proactively identify safety hazards before they become incidents and accidents (Mills, 2016). The aim of the IOSA program was to "formulate and implement IOSA as an internationally recognised evaluation system by which the level of competence and reliability of an airline to deliver a safe operation and manage attendant risks may be assessed" (Mills, 2016). According to Mills (2016), the IOSA program is seen as a proactive, voluntary operational (rather than regulatory) audit program that would complement the existing ICAO and civil aviation regulatory audits. The IOSA program has been a success (Mills, 2016). There were 405 airlines registered in IOSA in 2015, 150 of which were not members of IATA (Mills, 2016). The success of IOSA is tied to the issuance of the Safety Management Manual by ICAO (Doc 9859). Civil aviation regulators and air carriers were directed to implement self-auditing and voluntary reporting programs to proactively identify and address safety gaps in their organisations. This raised the profile and demand for IOSA (Mills, 2016). It has been indicated that the total accident rate for IOSA airlines between 2011 and 2015 was 3.3 times lower than the rate for non-IOSA operators (Mills, 2016). The success of the STEADES program will be discussed in section 4.

According to Mills (2016), the examples in aviation indicate that private regulatory programs can complement or even replace existing public sector regulatory regimes. The industries' voluntary programs can be effective and valuable for overcoming the obstacles in the implementation of safety management systems. 
Also Walker (2014) found that voluntary regulation and compliance programs can be effective. The programs such as NHVAS in Australia have been effective in improving the safety performance in truck transportation. According to Walker (2014), the crash rate of vehicles in NHVAS is lower than for non-accredited vehicles.

\subsection{Summary}

All transport industries have been in a constant transition towards more liberalised markets. The liberalisation and privatisation have led to fragmentation of the industries. While competition between transport operators has become harder and harder, the operators have been forced to restructure their operations. More and more transport operators are practically "virtual". For example, flagging ships out to FOC countries, using manning agencies for hiring personnel and outsourcing ship management are growing trends in the shipping business. Many airlines do not own their airplanes but lease them, and they subcontract training and maintenance as well as all support services. It is evident that the railway industry is following this trend as well. At the same time, the use of multinational and multicultural workforce is increasing significantly. Small and medium-sized transport companies in particular are facing enormous challenges in implementing their safety management systems under the fierce competition. Many companies would need help in implementing safety management systems.

It is evident that no company can manage implementing the safety management system properly using only its own resources. Besides the support and encouragement from administrative bodies, self-regulatory co-operation between companies is also needed to facilitate the implementation of safety management systems. The aviation and shipping industries provide excellent examples of successful industry self-regulation. Both industrial and governmental co-operation is needed to ensure that all operators will be engaged in these programmes.

\section{SMS obstacles for staff}

This section discusses the obstacles that employees have faced in the implementation of safety management systems. In addition, this section introduces the benefits brought to the employees by the implementation of safety management systems. Studies on the implementation of safety management systems have concentrated on associated difficulties and problems, while the benefits for employees have too often been taken for granted.

This section begins with introducing the importance of employee participation in implementing safety management systems. After that it is discussed how the employees' different approaches to safety culture may hinder the successful implementation of safety management systems. Third, this section discusses the difficulties and problems related to incident reporting. Fourth, this section introduces the benefits of safety management for the employees.

\subsection{Employee participation}

Working in the transportation industry can be risky for the staff regardless of the transport mode. Pilots, mariners, bus drivers and train drivers may put their own as much as passengers' lives at risk during their operations (Grote, 2012; Ek et al., 2014). The transportation staff can face danger by occupational accidents and operative disasters (Grote, 2012; Ek et al., 2014). Different working positions can cause different risk for the staff. For example, railway maintenance workers have to struggle to balance the demands of train safety, punctuality and production against their own 
occupational safety (Sanne, 2008). Similarly, maritime pilots have to balance between their personal safety, navigation safety and fluency of maritime traffic (Lappalainen et al., 2014).

According to Langard et al. (2013), the risk level in maritime transportation is close to 10-5 which is comparable to that in railway transportation but certainly higher than in air transportation (10-6)2. However, seafaring has remained among the most hazardous of occupations (Langard et al., 2013; Ek et al., 2014). According to Ek et al. (2014), conflicting safety and production goals, ineffective communication and time pressure may very likely lead to the stretching of safety margins and the migration of behaviour towards the boundary of acceptable performance (see also, Sanne, 2008). A strong safety culture among the staff is considered to be a fundamental preventive force towards risky behaviour and an important prerequisite for implementing safety management systems (Ek et al., 2014; Bhattacharya, 2009).

A crucial characteristic of a good safety culture is the possibility for the personnel to participate, and the delegation from upper management in safety related issues (Reason, 1997; Collins and Gadd, 2002; Wiegmann et al., 2002; Richter and Koch, 2004; Guldenmund, 2010). The empowerment of employees to work actively in the field of safety improves the staff attitudes and motivation towards safety (Wiegmann et al., 2002). According to Bhattacharya (2009), effective participation of employees is critical to the effective implementation of safety management. Multiple benefits of employee participation for implementing safety management systems have been recognised by several authors (Anderson, 2003; Bhattacharya, 2009; Oltedal, 2011; Lappalainen, 2016). The staff can play an important role in risk identification and in sharing their practical knowledge and skills to develop precautionary measures. Employee participation gives the staff an opportunity to contribute to the decision-making process on safety management systems, which strengthens their ownership of safety issues (Bhattacharya, 2009; Lappalainen, 2016). In addition, Bhattacharya (2009) argues that employee participation can lead to better standards of safety management.

On the other hand, Almklov et al. (2014) have found that implementing safety management systems based on a generic safety management regime may lead to disempowerment of employees and their perspectives. They fear that generic safety management principles and international standards may displace or marginalise existing local and system-specific safety knowledge (Almklov et al., 2014). The next section discusses that problem more thoroughly.

\subsection{Conflicting cultural approaches, a barrier for implementing SMS}

As stated above in section 2.2, organisational cultures are rarely totally integrated. The organisational culture can be differentiated and fragmented. When it comes to safety culture among staff, they can have a totally different approach towards safety than what was introduced in the management regimes based on generic safety management principles (Sanne, 2008; Antonsen, 2009; Knudsen, 2009; Grote, 2012; Almklov et al., 2014). Sanne (2008) found that railway maintenance workers viewed the safety management system from a different cultural frame based on their occupational etiology, which emphasises vigilance, care, skill and responsibility. Similar conclusions have been made by Knudsen (2009) and Antonsen (2009) who studied maritime personnel attitudes towards working by formal and written rules. They explained the maritime personnel's reluctant attitudes towards working by formal and written rules with the concept of seamanship (Knudsen, 2009) and incompatibilities between the occupational culture of seamen and the rule-based safety management approaches (Antonsen, 2009). In the same way as railway maintenance workers emphasise vigilance, care, skill and responsibility, seamen believe more in experience and know-how than in manuals and other documents describing the operations. Precise rules may, in their opinion, sometimes limit reasonable operations (Knudsen, 2009). According to Knudsen (2009), seamen have a well-established understanding on how to become a good seaman, which has evolved through history. According to the understanding of seamen, safety can only be ensured by seamanship that reflects a professional touch and professional pride that have developed through long hands-on experience (Knudsen, 2009). The staff has often seen the requirements contained in various instructions as distrust towards their own competence and professional skills (Bhattacharya, 2009). 
Several studies have found support for the above conclusions. Differences in cultural approaches have been reflected as problems and difficulties in the implementation of safety management systems. Problems and difficulties have been found both during the initiation phase of safety management systems and on the way towards their application. Pun et al. (2000) and Anderson (2003) give an example on the difficulties encountered in the early stages of implementation of the ISM Code in the maritime industry. Resistance to change appeared both among shipping companies and ship crews (Pun et al., 2002; Anderson, 2003). In the early stage the systems were made too burdensome and complex, so that the system was difficult to adopt and was seen as bureaucratic paper work (Anderson, 2003). Anderson (2003) considers it understandable that the personnel objected to this kind of safety management systems. In most cases the views of the ships' crew were not taken into consideration when drafting the contents of the documentation, and the training they received was not sufficient (Anderson, 2003; IMO, 2005). These factors reduced the motivation of the personnel to act as described in the safety management system (Pun et al., 2002; Anderson, 2003).

Later, these findings received support from Oltedal (2011), who found that the experience and expertise of the staff had not been appropriately utilised during the documentation work. This has led to inapplicable and incompatible system documentation which did not reflect the ships' real-life operations. Documentation that is incompatible is not likely to be followed in the actual operations (Antonsen, 2009; Kongsvik et al., 2014). Furthermore, Batalden and Sydnes (2014) claimed that poor instructions, checklists, and procedures which were not followed by the staff have contributed to some serious accidents.

In their recent study, Kongsvik et al. (2014) have claimed that the excessive documentation and increased paperwork has led to a bureaucratic culture and displaced the common sense incorporated in local practices. According to Sanne (2008), this has also happened in rail transportation (see also Almklov et al., 2014). The personnel may see the requirements contained in various instructions as distrust towards their own competence and professional skills (Sanne, 2008; Bhattacharya, 2009). According to Lofquist et al. (2017), the operation employees have experienced a constant struggle between rule compliance and practicality. The operation employees see the safety rules as carrying a negative meaning of being pushed down the hierarchy without consulting with them (Lofquist et al., 2017).

The criticism of excessive documentation is not purely a cultural problem. According to Lappalainen (2016), excessive documentation is related more or less to poor completion of the safety management system. Oltedal (2011) and Lappalainen (2016) conclude that the staff would be more committed and compliant with safety management if they had been more engaged in the documentation process. They (Oltedal, 2011; Lappalainen, 2016) believe that better integration of the operating personnel's experience and expertise will lessen the problems of excessive documentation. However, poor completion of safety management system documentation does not promote the progress of safety culture.

A new approach is also needed in the documentation process of safety management systems. According to Schröder-Hinrichs et al. (2015), the safety management regime is traditionally rooted in the safety-I paradigm. Safety management standards require that the companies have established procedures for the main functions and operations, and by that the companies are pushed directly into a 'work as imagined' perspective (Schröder-Hinrichs et al., 2015). When it comes to instructions related to safety management systems, this may mean that the work done by the employees differs from what was meant by the designers of the safety management system. As argued above, incompatible safety management documentation may not be followed in real-life operations (Antonsen, 2009; Oltedal, 2011; Kongsvik et al., 2014; Lappalainen, 2016). Documentation based on the 'work as imagined' perspective may also lead to marginalisation of local and system-specific safety knowledge (Almklov et al., 2014).

A new Safety II approach introduced by Hollnagel (2014) is proposed to substitute the traditional approach. According to Schröder-Hinrichs et al. (2015), the baseline of the safety-II approach is 
focusing on the 'work as done' perspective. The 'work as done' perspective requires that the employees' experience and expertise is harnessed more tightly to the documentation process. Engagement of employees in the documentation process will promote their commitment to the safety culture.

\subsection{Incident reporting and investigation}

Reporting and investigating incidents 3 is an integral component of continuous improvement in the safety management system (IMO, 2008; Grote, 2012). With the reporting system, it is possible to proactively identify any safety weaknesses and vulnerabilities in the organisation (Wiegmann et al., 2002; Eiff, 1999). According to Anderson (2003), a well-functioning reporting system indicates that the roots of the safety culture have been established. Bhattacharya (2009) sees that incident reporting serves as a mechanism to check the effectiveness of safety management systems by learning from errors. He regards incident reporting as an effective technique to detect any shortcomings in the way safety is managed in organisations (Bhattacharya, 2009). The reporting of incidents by staff has been seen as a significant indicator of a properly functioning safety management system (Anderson 2003; IMO 2005; Mejia 2001; Lappalainen, 2011). According to Mejia (2001), the willingness to report incidents is an indication of whether safety management systems are functioning as they should. According to Anderson (2003), a properly working reporting process is an indication that the cycle of continuous improvement is working as well (see for example Reason, 1997; Wiegmann et al., 2002; Anderson, 2003).

Incident reporting schemes have been widely used in safety-critical industries, such as the aviation industry, the nuclear power industry and health care services (Reiman et al., 2008). These industries have established procedures for incident reporting to improve their safety performance. In most cases, incident reporting procedures are required by law. In aviation, rail transportation and maritime transportation, the regulatory agencies require that companies establish procedures for incident reporting in order to improve safety (Reiman et al., 2008).

The maritime industry is also considered to be one of the safety-critical industries (Knudsen 2009). The ISM Code is the response of the maritime industry to incident reporting, since the Code strictly requires that incidents are reported and corrective actions are implemented. In the maritime industry, incident reporting has mostly been justified through the concept of the accident pyramid (Vepsäläinen and Lappalainen, 2010). The concept presumes that the number of accidents increases from fatal to serious casualties, less serious casualties and further to near-miss cases. According to the concept, serious and less serious casualties are caused by the same reasons, also known as the identical causation hypothesis. Incidents can be seen as precursors of accidents. However, the concept of the accident pyramid has been criticised (Salminen 2010). Serious and less serious casualties are the result of different root causes (Salminen 2010). This theory is called the different accident causation hypothesis (Salminen et al., 1992). The different accident causation hypothesis is supported by some empirical studies (see for example Kines 2002; Carter and Menckel 1985). According to Hale (2001), presupposing that the causes of minor and major incidents are similar can lead the analysis of the incident astray and thus cause the organisation to take unsuitable preventive actions.

Despite the criticism towards the common root cause argument, the importance of reporting nearmiss occurrences is widely acknowledged (Bhattacharya, 2009; Grote, 2012). In order to prevent future accidents there is a need to learn from incidents and make improvements through developing technology, modifying the organisational structure and organisational routines, providing training and taking other measures (Bhattacharya 2009). In addition, some studies have found positive correlation between active reporting and improved safety performance. According to Jones et al. (1999), a high frequency of incident reporting decreases the occurrence of occupational injuries (see also Lanne et al., 2006).

Incident reporting in the transportation industry has been the focus of several studies. For example, Sanne (2007) has studied reporting practises among railway maintenance workers, Bhattacharya 
(2009) and Oltedal (2011) have studied incident reporting among maritime personnel, and Teperi and Leppänen (2010) have studied learning from incidents in air navigation services.

Unfortunately, the studies have indicated that incident reporting is not carried out properly. Underreporting and differential reporting are the main difficulties related to incident reporting. What is more, there is a lack of systematic analysis, corrective actions and feedback from management (Sanne, 2007; Teperi and Leppänen, 2010; Oltedal, 2011; Grote, 2012; Lappalainen, 2016). The blame culture has been claimed to be a major reason for poor reporting. According to Sanne (2008), the blame culture has evolved from a fear of social sanctions from reporting. The social sanctions can include shame, blame, and disciplinary actions (Sanne 2008). The employees' fear of being blamed by their managers may prevent them from reporting incidents or near-miss occurrences. This includes the senior officers' fear of criminalisation, peer pressure among ratings and the officers' tendency to accept risk as a part of their work (Bhattacharya 2009).

Although shame and blame are considered as the major reasons for poor reporting, there are other culturally-based reasons for non-reporting. As stated in the previous section, cultural incompatibilities exist between the employees' occupational culture and the rule-based safety management approaches, which presume that reporting is not a way to learn from incidents (Sanne, 2008; Knudsen, 2009; Lappalainen, 2016). Thus, incident reporting does not serve the interests of the personnel (Sanne 2008). According to Sanne (2008), poor or inappropriate feedback from reports submitted reinforce the employees' mistrust towards the formal reporting system. What is more, negative feedback helps to maintain the blame culture (Sanne 2008).

A more promising example can be found in aviation (Mills, 2016). According to Mills (2016), the number of incident reports increased considerably in the STEADES System (Safety Trend Evaluation and Data Exchange System operated by IATA) during the 2000s. STEADES is an aviation safety incident data management and analysis programme, which is the world's largest source of deidentified incident reports with over 160,000 reports from 177 participating air carriers collected in 2013 (Mills, 2016). The level of reporting also increases - even if the overall number of incidents decreases. Mills (2016) has found several explanations for the growth of reporting. First, the programme is voluntary, and trust among participants has been built through adherence to nonpunitive action, confidentiality, ease of reporting, promotion of findings, and acknowledging the importance of reporting across the industry. Second, the growth of STEADES was tied to the issuance of the Safety Management Manual by ICAO (Doc 98599), which called for civil regulators and air carriers to establish voluntary reporting programmes within their organisations. The new guidance required that regulators and air carriers integrate the data from these programmes into their safety oversight systems. This increased the demand for benchmarks and trends and thus for aggregated safety data provided by STEADES (Mills, 2016).

Another successful example can be found in the Norwegian railways (Elvik and Voll, 2014). According to statistics published by the railway safety inspectorate, the number of incidents reported on mainline railways increased from 2722 in 2002 to 15,995 in 2011 (Elvik and Voll, 2014). According to Elvik and Voll (2014), an interpretation for the increase of reports could be that the true number of incidents has not increased so much, but that reporting has improved. Elvik and Voll (2014) suppose that when the incident reporting system was quite new in 2002, there was a reluctance to report incidents due to fear of getting negative feedback from management. Later the system became better known and the staff found that reporting incidents did not have negative consequences, for which reason the reporting activity increased (Elvik and Voll, 2014). In addition, the reporting of incidents is now strongly encouraged. However, Elvik and Voll (2014) suppose that there could be other interpretations for the increased number of reports. First, more incidents may have occurred and therefore been reported. Second, the increase in the number of reports may show that vigilance among railway staff is increasing.

Regardless of those two promising examples of successful incident reporting, some novel approaches are needed in order to promote better incident reporting. 
According to Teperi and Leppänen (2010), effective learning methods may be missing even in high-risk organisations. For example, self-reflection skills were not utilised in learning from incidents (Teperi and Leppänen, 2010). What is more, they considered that the reporting of incidents has focused too much on mistakes and errors. The focus should be changed from negative effects to positive human factors (Teperi et al., 2015).

As stated in the previous section, a new paradigm is needed in safety management and, particularly, in incident reporting. The traditional approach to incident reporting could be characterised by the concept of safety-I, which focuses on reactive responses and where safety is improved through eliminating the causes of human failures and errors. The concept of safety-II, on the other hand, considers humans a resource of successful performance (Hollnagel, 2014; SchröderHinrichs et al., 2015; Teperi et al., 2015).

Teperi et al. (2015) argue that in order to motivate and encourage employees to report incidents more actively, it is important to highlight the positive role of human activity in coping with unexpected events and the strengths and capabilities of human operators, rather than focusing on human errors and risks. Teperi et al. (2015) have designed and tested a new tool (HF Tool) which incorporates the safety-II approach and human factors to safety management in different industries (see also, Teperi, 2016 ). In 2008, the HF Tool was tested in the Finnish Air Traffic Management to support the skills of operative personnel and management in analysing the success and weakness factors behind operative incidents on the individual, group, work and organisational level (Teperi et al., 2015). In 2016, the HF Tool was tested at the Finnish shipping industry (Teperi et al., 2017, submitted).

Ek and Arvidsson (2012) have also proposed that individual knowledge and awareness about safety issues should be increased by providing training in the area of human factors and specifically organisational factors in air traffic control organisations. According to Ek and Arvidsson (2012), other key enablers for safety improvement could be involving all organisational levels in the identification and discussion of potential safety problems, and providing sufficient time for the employees to discuss and reflect on safety issues as well as for implementation and follow-up.

It was found that focusing on positive human factors as emphasised in the HF tool, for example, and understanding humans as a resource of successful performance could motivate and encourage employees to report incidents more actively and thus promote the rooting of a positive safety culture in organisations (Teperi et al., 2015; Teperi et al., 2017, submitted). Focusing on positive human factors could also facilitate establishing trust in reporting among staff.

Reiman et al. (2012) call for "just culture" in order to promote incident reporting. They have found that the success of incident reporting in the aviation industry is based on a no-blame and nopunishment philosophy, where the focus is on finding solutions to and improvements in safety issues. The concept of just culture entails a climate of trust and fairness in organisations (Reiman et al., 2012).

\subsection{Benefit of SMS for staff}

The introduction of safety management regimes has rested on the presumption that the implementation of a safety management system provides inevitable benefits to its users as companies and their staff. Several studies have indicated that the implementation of a safety management system would result in increased safety performance of an organisation and provide even better profit. However, the direct impact on improved safety performance has been difficult to demonstrate because relevant statistics on safety levels are not available (Bhattacharya, 2009) However, some studies have indicated that the adoption and implementation of safety management systems has reduced the number of accidents (Knapp and Frances, 2009) and the share of human factors in maritime accidents (Tzannatos and Kokotos, 2009). 
Nevertheless, those studies are rare where the benefits of the implementation of a safety management system have been investigated from the employee's point of view. Lappalainen (2016) has studied what benefits the maritime personnel have gained from the implementation of safety management systems in their daily operations. Although his study indicated several fundamental difficulties in the implementation of safety management systems, the maritime personnel regarded safety management systems at the general level as beneficial and essential for supporting them in accomplishing their daily tasks (Lappalainen, 2016). According to Lappalainen (2016), the maritime staff was quite unanimous about the benefits. The criticism was targeted to the completion of safety management systems, not against the general usefulness of safety management (Lappalainen, 2016).

A major benefit from the employees' point of view is that the safety management regulation requires companies to take overall responsibility for safety by introducing the safety management system (Lappalainen, 2016). The personnel that Lappalainen (2016) interviewed shared the opinion that the responsibility imposed by the ISM Code on the company and its management is one of the most significant benefits with regard to safety. In addition, the study indicated that one of the advantages of the safety management system is that it has clarified the roles and responsibilities onboard as they are defined in the system. The roles and responsibilities have been clarified both on the ship and between the ship and the shipping company. The clarified roles and responsibilities provide several concrete benefits to the personnel: they know who to contact and can rely on that the company must take a stand on the matter. What is more, the clarified roles and responsibilities facilitate better communication between the ships and the office (Lappalainen, 2016).

Another benefit is that safety management systems have unified and systematised the procedures on-board, which has made the maritime personnel's job much easier. Unified and systematised procedures have made it easier to train new employees, and for the personnel to transfer from one ship to another. It is beneficial that safety-related procedures have been documented and the necessary instructions can be easily found. The users can rely on that they are using correct, current and accepted procedures as provided by the safety management system documentation. The staff does not have to learn new issues by trial and error. Moreover, unified procedures and system documentation maintain the continuity of good practices on-board when crew members are changing (Lappalainen, 2016).

\subsection{Summary}

As presented above, conclusions on the implementation of safety management systems are contradictory from the point of view of the staff. On the one hand, employees have experienced significant benefits from the implementation of safety management systems, but on the other hand, serious deficiencies and obstacles have also been reported. Incident reporting in particular has led to contradictory conclusions. Employees have regarded incident reporting as important, but at the same time they have expressed strong criticism towards the implementation of incident reporting systems.

A new paradigm that incorporates the safety-II approach and human factors has been proposed in order to overcome the difficulties and to motivate and encourage the staff to actively participate in implementing safety management systems.

The employees' experience and expertise should be better engaged in the implementation of safety management systems. Focusing on positive human factors and understanding humans as a resource of successful performance could motivate and encourage employees to report incidents more actively and thus promote the rooting of a positive safety culture in organisations. Individual knowledge and awareness in the area of human and organisational factors should be increased. All levels of the organisation should be involved in the identification and discussion of potential safety problems. Sufficient time should be provided for the employees to discuss and reflect on safety issues as well as for implementation and follow-up. 


\section{Conclusions}

The purpose of this paper has been to examine the obstacles to implementing safety management systems and to discuss the possible solutions for overcoming those obstacles among the four transport modes: aviation, maritime, rail and road. It was shown that the difficulties and problems in implementing safety management systems often originate in the specific cultural features of an organisation or an occupation. In addition, safety-related attitudes and practices are strongly influenced by the national culture. There can be good and bad safety cultures in relation to an organisation's basic assumptions, but there is no single truth about what kind of safety culture would be the best in a particular organisational context. Instead of prescribing and regulating a safety culture, organisations and regulators should carefully consider the basic assumptions that could be cultural enablers and cultural barriers for the organisation in implementing safety management systems.

However, the basic assumptions are difficult to recognise and assess. What is more, they are difficult to change. To avoid that specific basic assumptions become a barrier for implementing safety management systems, the employees' experience and expertise should be employed more intensively in the implementation work. A key enabler for safety improvement would be to involve all organisational levels in the identification, discussion and implementation of potential safety issues.

New thinking is needed in safety management and, particularly, in incident reporting. Focusing on positive human factors and understanding humans as a resource of successful performance could motivate and encourage employees to report incidents more actively and thus promote the rooting of a positive safety culture in organisations.

The transport industry is in constant transition towards more liberalised markets, which will lead to more fragmented industry structures. Because of new organisational boundaries, the fragmentation will increase coordination problems between the operators and thus cause extra challenges for the implementation of safety management systems. It is evident that no company can manage implementing the safety management system properly using only its own resources. Co-operation between companies is needed, and the regulatory agencies should provide support for that cooperation. The industries' voluntary co-operation programmes have proved to be effective and valuable for overcoming any obstacles in the implementation of safety management systems. 


\section{References}

Alexandersson, G., and K. Riga (2013), "Rail liberalisation in Sweden. Policy development in a European context". Research in Transportation Business and Management, Vol. 6, pp. 88-98.

Allaire, Y. and M.E. Firsirotu (1984), "Theories of organizational culture". Organization Studies, Vol. 5/3, 193-226.

Almklov, P.G., R. Rosness and K. Størkersen (2014), "When safety science meets the practitioners: Does safety science contribute to marginalization of practical knowledge?" Safety science, Vol. 67, pp. 25-36.

Alvesson, M. (2002), Understanding organisational culture. SAGE Publications, London.

Amalberti, R. (2001), "The paradoxes of almost totally safe transportation systems". Safety science, Vol. 37/2, pp. 109-126.

Anderson, P. (2003), Cracking the code: the relevance of the ISM code and its impact on shipping practices. Nautical Institute, London.

Antonsen, S. (2012), Safety culture: theory, method and improvement. Ashgate Publishing Farnham.

Barley, S.R. and G. Kunda (1992), "Design and devotion: Surges of rational and normative ideologies of control in managerial discourse". Administrative Science Quarterly, Vol. 37/3, pp. 363-399.

Batalden, B.M. and A.K. Sydnes (2014), "Maritime safety and the ISM code: A study of investigated casualties and incidents". WMU Journal of Maritime Affairs, Vol. 13/1, pp. 3-25.

Baylon, A.M. and E.M.R. Santos (2011), "The Challenges in Philippine Maritime Education and Training”. International Journal of Innovative Interdisciplinary Research, Vol. 1/1, pp. 34-43.

Berg, N., J. Storgård and J. Lappalainen (2013), "The impact of ship crews on maritime safety". Publications of the Centre for Maritime Studies, University of Turku.

Beria, P., E. Quinet, G. De Rus and C. Schulz (2012), “A comparison of rail liberalisation levels across four European countries". Research in Transportation Economics, Vol. 36/1, pp. 110120.

Bhattacharya, S. (2009), Impact of the ISM Code on the Management of Occupational Health and Safety in the Maritime Industry. (Doctoral Thesis), Cardiff University, Cardiff.

Bhattacharya, S. and L. Tang (2013), "Middle managers' role in safeguarding OHS: The case of the shipping industry”. Safety Science, Vol. 51/1, pp. 63-68.

Bhattacharya, Y. (2015), "Employee engagement in the shipping industry: A study of engagement among Indian officers". WMU Journal of Maritime Affairs, Vol. 14/2, pp. 267-292.

Braut, G.S., Ø. Solberg and O. Njå (2014), "Organizational effects of experience from accidents. Learning in the aftermath of the Tretten and Åsta train accidents". Transportation Research Part A: Policy and practice, Vol. 69, pp. 354-366.

Cariou, P. and F.C. Wolff (2015), "Identifying substandard vessels through Port State Control inspections: A new methodology for Concentrated Inspection Campaigns". Marine Policy, Vol. 60, pp. 27-39.

Carter, N. and E. Menckel (1985), "Near-accident reporting: A review of Swedish research". Journal of Occupational Accidents, Vol. 7, pp. 41-64.

Collins, A.M. and S. Gadd (2002), "Safety Culture: A review of the literature". Health and Safety Laboratory. Human Factors Group, Sheffield. 
Crackel, L. and M. Small (2010, September), ISO 39001: a new tool for safe systems. In Insurance Commission of WA Road Safety Forum.

CSSF (2016), Container Ship Safety Forum (CSSF), http://www.cssf.global/

Delaplace, M. and F. Dobruszkes (2015), "From low-cost airlines to low-cost high-speed rail? The French case". Transport policy, Vol. 38, pp. 73-85.

Demers, C. (2007), Organizational change theories: A synthesis. SAGE Publications, London.

DIRECTIVE (EU) 2016/798 (2016) European Railway Safety Directive, of the European Parliament and of the Council, 11 May 2016. http://eur-lex.europa.eu/legalcontent/EN/TXT/?uri=uriserv:OJ.L_.2016.138.01.0102.01.ENG

EASA (2016), Safety Management System (SMS). European Aviation Safety Agency. https://www.easa.europa.eu/easa-and-you/safety-management/safety-management-systemsms

Edwards, J.R., J. Davey and K. Armstrong (2013), "Returning to the roots of culture: A review and re-conceptualisation of safety culture". Safety science, Vol. 55, pp. 70-80.

Eiff, G. (1999), "Organizational safety culture". In Jensen, R.S. (Ed.), Proceedings of the $10^{\text {th }}$ International Symposium on Aviation Psychology. Columbus, Ohio. pp.778-783.

Ek, Å., R. Akselsson, M. Arvidsson and C.R. Johansson (2007), "Safety culture in Swedish air traffic control”. Safety Science, Vol. 45/7, pp. 791-811.

Ek, Å. And M. Arvidsson (2012), "Enabler for safety improvements in air traffic control”. Aviation Psychology and Applied Human Factors, Vol. 2/2, pp. 82-94.

Ek, Å., M. Runefors and J. Borell (2014), "Relationships between safety culture aspects: A work process to enable interpretation”. Marine Policy, Vol. 44, pp. 179-186.

El-Koursi, E., S. Mitra and G. Bearfield (2007), "Harmonising safety management systems in the european railway sector". Safety Science Monitor, Vol. 11/2, p. 14.

Elvik, R. and N.G. Voll (2014), "Challenges of improving safety in very safe transport systems". Safety Science, Vol. 63, pp. 115-123.

ERA (2016), Welcome to the Safety Management Systems (SMS). European Railway agency. http://www.era.europa.eu/tools/sms/Pages/SMS.aspx

Evans, A.W. (2013), "The economics of railway safety". Research in Transportation Economics, Vol. 43/1, pp. 137-147.

Evans, A.W. (2010), "Rail safety and rail privatisation in Japan". Accident Analysis and Prevention, Vol. 42, pp. 1296-1301.

Evans, A.W. (2007), "Rail safety and rail privatization in Britain". Accident Analysis and Prevention, Vol. 39, pp. 510-523.

Fan, L., M. Luo and J. Yin (2014), "Flag choice and Port State Control inspections: Empirical evidence using a simultaneous model". Transport Policy, Vol. 35, pp. 350-357.

Gill, G.W. and C.M. Wahner (2012), "The Herald of Free Enterprise Casualty and Its Effect on Maritime Safety Philosophy”. Marine Technology Society Journal, Vol. 46/6, pp. 72-84.

Glendon, A.I. and N.A. Stanton (2000), "Perspectives on safety culture". Safety Science, Vol. 34/1, pp. 193-214.

Goulielmos, A.M. (2001), "Maritime safety: facts and proposals for the European OPA". Disaster Prevention and Management, Vol. 10/4, pp. 278-285.

Goulielmos, A.M. and A. Gatzoli (2012), "The role of a ship's Master in theory and practice: Lessons from Marine Accidents”. Critical Incident Analysis, Fall 2012, pp. 55-78. 
Grote, G. (2012), "Safety management in different high-risk domains: All the same?". Safety Science, Vol. 50/10, pp. 1983-1992.

Guldenmund, F.W. (2014), “Organisational safety culture principles". In Waterson, P. (Ed.), Patient Safety Culture: Theory, Methods and Application, pp. 15-42, Ashgate, Farnham.

Guldenmund, F.W. (2010), Understanding and exploring safety culture. TU Delft, Delft University of Technology.

Hale, A. (2001), "Conditions of occurrence of major and minor accidents". Journal of the Institution of Occupational Safety and Health, Vol. 5/1, pp. 7-21.

Haukelid, K. (2008), "Theories of (safety) culture revisited: An anthropological approach". Safety Science, Vol. 46/3, pp. 413-426.

Heij, C., G.E. Bijwaard and S. Knapp (2011), "Ship inspection strategies: Effects on maritime safety and environmental protection". Transportation Research Part D: Transport and Environment, Vol. 16/1, pp. 42-48.

Hetherington, C., R. Flin and K. Mearns (2006), "Safety in shipping: The human element". Journal of Safety Research, Vol. 37/4, pp. 401-411.

Hollnagel, E. (2014), Safety-I and Safety-II: The past and future of safety management. Ashgate Publishing, Ltd.

Hystad, S.W., E.R. Saus, B. Sætrevik and J. Eid (2013), "Fatigue in seafarers working in the offshore oil and gas re-supply industry: effects of safety climate, psychosocial work environment and shift arrangement”. Int Marit Health, Vol. 64/2, pp. 72-79.

Håvold, J. (2007), "National cultures and safety orientation: A study of seafarers working for Norwegian shipping companies". Work and Stress, Vol. 21/2, pp. 173-195.

Hämäläinen, P. and J. Heikkilä (2013), Poikkeamaraportointi ammattiliikenteessä. Väline turvallisuusjohtamiseen tieliikenteessä. (Incident reporting. Measure for safety management in road traffic). VTT Technology, 85.

ICAO (2013), Doc 9859, Safety Management Manual (SMM), V.3, International Civil Aviation Organisation, http://www2.icao.int/en/ism/Pages/GuidanceMaterials.aspx

IMO (2008), Adoption of amendments to the international management code for the safe operation of ships and for pollution prevention (International Safety Management (ISM) Code), Resolution MSC 273(85).

IMO (2005), Role of the Human Element: Assessment of the impact and effectiveness of implementation of the ISM Code, International Maritime Organisation, MSC 81/17.

IMO (1993), The international management code for the safe operation of ships and for pollution prevention (International Safety Management (ISM) Code), Resolution A.741(18).

Jense, G. (2009), ISM-koden: den svenska erfarenheten i ett globalt sjösäkerhetsperspektiv. Växjö University.

Johansson, M. (2011), "ISO 39001 Road Traffic safety (RTS) management systems-experiences from early adopters in the Swedish transport industry". In International Symposium on Heavy Vehicle Transport Technology (Vol. 12).

Jones, S., C. Kirchsteiger and W. Bjerke (1999), "The importance of near miss reporting to further improve safety performance". Journal of Loss Prevention in the Process Industries, Vol. 12, pp. 59-67.

Jupe, R. and G. Crompton (2006), "A deficient performance: The regulation of the train operating companies in Britain's privatised railway system". Critical perspectives on accounting, Vol. 17/8, pp. 1035-1065. 
Kines, P. (2002), “Construction workers' falls through roofs: Fatal versus serious injuries”. Journal of Safety Research, Vol. 33, pp. 195-208.

Kines, P., J. Lappalainen, K.L. Mikkelsen, E. Olsen, A. Pousette, J. Tharaldsen ... and M. Törner (2011), "Nordic Safety Climate Questionnaire (NOSACQ-50): A new tool for diagnosing occupational safety climate". International Journal of Industrial Ergonomics, Vol. 41/6, pp. 634-646.

Knapp, S. and P.H. Franses (2009) "Does ratification matter and do major conventions improve safety and decrease pollution in shipping?" Marine Policy, Vol. 33/5, pp. 826-846.

Knapp, S. and P.H. Franses (2007), "Econometric analysis on the effect of port state control inspections on the probability of casualty: Can targeting of substandard ships for inspections be improved?" Marine Policy, Vol. 31/4, pp. 550-563.

Knights, D. (2002), "Writing organizational analysis into Foucault". Organization, Vol. 9/4, pp. 575-593.

Knudsen, F. (2009), "Paperwork at the service of safety? Workers' reluctance against written procedures exemplified by the concept of 'seamanship"'. Safety Science, Vol. 47/2, pp. 295303.

Knudsen, O.F. and B. Hassler (2011), "IMO legislation and its implementation: accident risk, vessel deficiencies and national administrative practices". Marine Policy, Vol. 35/2, pp. 201-207.

Kongsvik, T.Ø., K.V. Størkersen and S. Antonsen (2014), "The relationship between regulation, safety management systems and safety culture in the maritime industry". In Steenbergen, R.D.J.M., P.H.A.J.M. van Gelder, S. Miraglia and A.C.W.M. Vrouwenvelder (Eds), Safety, Reliability and Risk Analysis: Beyond the Horizon. pp. 467-473, Taylor and Francis Group, London.

Kultalahti, A. (2015), Tieliikenteen tavarankuljetusyritysten vastuullisuusmalli ja sen vaikutukset. University of Helsinki, Department of Economics.

Kuronen, J. and U. Tapaninen (2010), "Evaluation of maritime safety policy instruments". WMU Journal of Maritime Affairs, Vol. 9/1, pp. 45-61.

Langard, B., G. Morel and C. Chauvin (2013), "Safety Culture and Operational Safety Management". In Maritime Transportation.

Lanne, M., M. Murtonen, M. Nissilä, K. Ruuhilehto and K. Virolainen (2006), Opas vaaratilanneraportoinnin kehittämiseen ja arviointiin (Guidance on development and assessment of incident reporting) VTT, Tampere. http://www.vtt.fi/inf/julkaisut/muut/2006/opas_vaaratilanneraportointi.pdf.

Lappalainen, J. (2016), Finnish maritime personnel's conceptions on safety management and safety culture, (Doctoral thesis, monograph), Annales Universitatis Turkuensis A II 316, University of Turku, Turku.

Lappalainen, J. (2008), “Transforming Maritime Safety Culture. Evaluation of the impacts of the ISM Code on maritime safety culture in Finland". Publications from the Centre for Maritime Studies, University of Turku, A 46.

Lappalainen, J. and K. Salmi (2009) "Safety Culture and Maritime Personnel's Safety Attitudes: Interview Report". Publications from the Centre for Maritime Studies, University of Turku, A 48.

Lappalainen, J., V. Kunnaala and U. Tapaninen (2014), "Present pilotage practices in Finland". WMU journal of maritime affairs, Vol. 13/1, pp. 77-99.

Lappalainen, J., J. Kuronen U. and Tapaninen (2012), "Evaluation of the ISM Code in the Finnish shipping companies". Journal of Maritime Research, Vol. 9/1, pp. 23-32. 
Lappalainen, J., A. Vepsäläinen, K. Salmi and U. Tapaninen (2011), "Incident reporting in Finnish shipping companies". WMU Journal of Maritime Affairs, Vol. 10/2, pp. 167-181.

Lappalainen, J., J. Storgård and U. Tapaninen (2013) "The effectiveness of maritime safety policy instruments from the Finnish maritime experts' point of view-case Gulf of Finland and prevention of an oil accident". TransNav: International Journal on Marine Navigation and Safety of Sea Transportation, Vol. 7/3.

Liimatainen, H., L. Nykänen, T. Hyytinen and J. Vasara (2014), Tieliikenteen tavarankuljetusyritysten vastuullisuusmalli - kokeilututkimus, Trafi Research Reports $03 / 2014$

Lloyds List, (November 2016).

Lofquist, E.A. (2008), Measuring the effects of strategic change on safety in a high reliability organization (Doctoral dissertation), Norwegian School of Economics and Business Administration.

Lofquist, E.A., P.K. Dyson and S.N. Trønnes (2017), "Mind the gap: A qualitative approach to assessing why different sub-cultures within high-risk industries interpret safety rule gaps in different ways". Safety Science, Vol. 92, pp. 241-256.

Lützhöft, M., M.R. Grech and T. Porathe (2011), "Information environment, fatigue, and culture in the maritime domain". Reviews of Human Factors and Ergonomics, Vol. 7/1, pp. 280-322.

Martin, J. (2007), "Politics of Organizational Culture". In Clegg, S. and J.R. Bailey (Eds.), International Encyclopedia of Organization Studies. SAGE Publications, London.

Mason, K., W.G. Morrison and I. Stockman (2016), "Liberalization of air transport in europe and the evolution of 'Low-cost'airlines". Liberalization in Aviation: Competition, Cooperation and Public Policy, Vol. 141.

Maurino, D. (2016), Email notification. 13 December 2016

McAuley, J., J. Duberley and P. Johnson (2007) Organization Theory: Challenges and perspectives. Prentice Hall, London.

Mejia, M. (2001), Performance Criteria for the International Safety Management (ISM) Code. Proceedings of the $2^{\text {nd }}$ General Assembly of IAMU International Association of Maritime Universities, Kobe, Japan.

Mills, R.W. (2016), "The interaction of private and public regulatory governance: The case of association-led voluntary aviation safety programs". Policy and Society, Vol. 35/1, pp. 43-55.

Mårtensson, M. (2006), Sjöfarten som ett socialt system. Om handelssjöfart, risk och säkerhet. Arbetsvetenskap, Luleå tekniska universitet, Luleå.

Noort, M.C., T.W. Reader, S. Shorrock and B. Kirwan (2015), "The relationship between national culture and safety culture: Implications for international safety culture assessments". Journal of Occupational and Organizational Psychology.

Nykänen, L. and K. Karhula (2015), Tieliikenteen tavarankuljetusyritysten vastuullisuusmalli ohjeistus ja käyttöliittymä. Trafi Research Reports 2/2015.

Oedewald, P. and T. Reiman (2007), Special characteristics of safety organizations. Work psychological perspective (No. VTT-PUB--633). VTT Technical Research Centre of Finland.

Ojala, T. (2013), Turvallisuusjohtaminen ja raskasta ammattiliikennettä ohjaava lainsäädäntö. (English abstract).Trafi Publications 21/2013.

Oltedal, H.A. (2011), "Safety culture and safety management within the Norwegian-controlled shipping industry. State of art, Interrelationships and Influencing Factors". (Doctoral Thesis), University of Stavanger, Stavanger. 
Oltedal, H.A. and D.P. McArthur (2011), "Reporting practices in merchant shipping, and the identification of influencing factors". Safety Science, Vol. 49/2, pp. 331-338.

Paris MoU (2008), Evaluation CIC on ISM in 2007, Paris MoU on Port State Control, Port State Control Committee 41st session, 19-23 May 2008, Loutraki.

Pellegrini, P. and J. Rodriguez (2013), "Single European sky and single European railway area: A system level analysis of air and rail transportation". Transportation Research Part A: Policy and Practice, Vol. 57, pp. 64-86.

Pidgeon, N. (1998), "Safety culture: key theoretical issues". Work and Stress, Vol. 12/3, pp. 202216.

Popescu, C., A. Varsami, C. Panait, E. Barsan, A. Bulucea, N. Mastorakis and C. Long (2010), Maritime English - A Necessity for Nowadays Apprentices. In proceedings of the 3rd International Conference of Advances in Maritime and Naval Science and engineering, September 2010, Constantza.

Pun, K.F., R.C. Yam and W.G. Lewis (2003), "Safety management system registration in the shipping industry". International Journal of Quality and Reliability Management, Vol. 20/6, pp. 704-721.

Pyne, R. and T. Koester (2005), "Methods and Means for Analysis of Crew Communication in the Maritime Domain". The Archives of Transport, Vol. 17/3-4, pp. 193-208.

Raines, M.S. (2011), "Engaging employees: Another step in improving safety". Professional Safety, Vol. 56/4, p. 36.

Ravira, F.J. and F. Piniella (2016), "Evaluating the impact of PSC inspectors' professional profile: a case study of the Spanish Maritime Administration". WMU Journal of Maritime Affairs, pp. $1-16$.

Reader, T.W., M.C. Noort, S. Shorrock and B. Kirwan (2015), "Safety sans Frontieres: an international safety culture model". Risk analysis, Vol. 35/5, pp. 770-789.

Reason, J.T. (1997), Managing the risks of organisational accidents. Ashgate, Aldershot.

Reiman, T. and P. Oedewald (2007), "Assessment of Complex Sociotechnical Systems-Theoretical issues concerning the use of organisational culture and organisational core task concepts". Safety Science, Vol. 45/7, pp. 745-768.

Reiman, T., E. Pietikäinen and P. Oedewald (2008) Turvallisuuskulttuuri: Teoria ja arviointi. VTT Technical Research Centre of Finland, Espoo.

Reiman, T. and P. Oedewald (2009) Evaluating safety critical organizations-emphasis on the nuclear industry. Finland: VTT.

Reiman, T., A. Silla, J. Heikkilä, E. Pietikäinen and J. Luoma (2012) Turvallisuuskulttuuri liikennejärjestelmässä. Esitutkimus. (Safety culture of different transport mode. A preliminary study, abstact) VTT 43s, p. 18.

Richter, A. and C. Koch (2004), "Integration, differentiation and ambiguity in safety cultures". Safety Science, Vol. 42/8, pp. 703-722.

Rodríguez, E. and F. Piniella (2014), "The New Inspection Regime of the Paris Mou on Port State Control: Improvement of the System". Journal of Maritime Research, Vol. 9/1, pp. 9-16.

Roe, M. (2016), "Corporate Social Responsibility and the governance of international shipping", Baltic Rim Economies, Vol. 5, pp. 23-24.

Rothblum, A.M., D. Wheal, S. Withington, S.A. Shappell, D.A. Wiegmann, W. Boehm and M. Chaderjian (2002), Human factors in incident investigation and analysis. Coast Guard Research and Development Center, Groton. 
Salminen, S., J. Saari, K.L. Saarela and T. Räsänen (1992), "Fatal and non-fatal occupational accidents: identical versus differential causation”. Safety Science, Vol. 15, pp. 109-118.

Salminen, S. (2010), Tapaturmateoriat ajan saatossa: taipumuksesta kimmoisuuteen (Different accident theories). Finnish Institute of Occupational Health. www.ttl.fi.

Salokorpi, M. and J. Rytkönen (2010), Turvallisuusjohtamisen parhaita käytäntöjä merenkulkijoille ja satamille. Kymenlaakson ammattikorkeakoulun julkaisuja. Sarja B. Nro 66.

Sampson, H. and M. Zhao (2003), "Multilingual crews: communication and the operation of ships". World Englishes, Vol. 22/1, pp. 31-43

Sanne, J.M. (2008), "Incident reporting or storytelling? Competing schemes in a safety-critical and hazardous work setting”. Safety Science, Vol. 46/8, pp. 1205-1222.

Schein, E.H. (1992), Organisational culture and leadership. John Wiley and Sons, San Francisco.

Schröder-Hinrichs, J.U., G. Praetorius, A. Graziano, A. Kataria and M. Baldauf (2015), Introducing the Concept of Resilience into Maritime Safety. http://commons.wmu.se/marisa_papers/1/

Schultz, M. and M.J. Hatch (1996), "Living with multiple paradigms the case of paradigm interplay in organizational culture studies". Academy of Management Review, Vol. 21/2, pp. 529-557.

Schwatka, N.V., S. Hecker and L.M. Goldenhar (2016), "Defining and measuring safety climate: A review of the construction industry literature". Annals of occupational hygiene, Vol. 60/5, pp. 537-550.

Silla, A. and J. Luoma (2014), Turvallisuuden ja toimintavarmuuden hallinta tieliikenteen kuljetusyrityksissä. (Management of safety and reliability in road transport companies). VTT Technology 149.

SM ICG (2010), Safety Management International Collaboration Group, Terms of Reference.

Smircich, L. (1983), "Concepts of culture and organisational analysis". Administrative Science Quarterly, Vol. 28/3, pp. 339-358.

Strauch, B. (2010), "Can cultural differences lead to accidents? Team cultural differences and their effects on sociotechnical system operations". Human Factors: The Journal of the Human Factors and Ergonomics Society.

Strauch, B. (2015), “Can we examine safety culture in accident investigations, or should we?" Safety Science, Vol. 77, pp. 102-111.

Swedish Association of Road Transport Companies (2012), Swedish company first in the world to be ISO 39001-certified. Press Release.

Teperi, A.M., and A. Leppänen (2010), "Learning at air navigation services after initial training". Journal of Workplace Learning, Vol. 22/6, pp. 335-359.

Teperi, A.M., A. Leppänen and L. Norros (2015), "Application of new human factors tool in an air traffic management organization”. Safety science, Vol. 73, pp. 23-33.

Teperi, A.M. (2016), "603 Modifying human factor tool for work places-development processes and outputs”. Injury Prevention, Vol. 22/2, pp. A216.

Teperi, A.M., J. Lappalainen, P. Perttula and V. Puro (forthcoming), Assessing maritime safety culture - current state and prerequisites to improve it.

Theotokas, I. and M. Progoulaki (2007), "Cultural diversity, manning strategies and management practices in Greek shipping”. Maritime Policy and Management, Vol. 34/4, pp. 383-403.

Tzannatos, E. and D. Kokotos (2009), "Analysis of accidents in Greek shipping during the pre-and post-ISM period”. Marine Policy, Vol. 33/4, pp. 679-684. 
Wachter, J.K. and P.L. Yorio (2014), "A system of safety management practices and worker engagement for reducing and preventing accidents: An empirical and theoretical investigation". Accident Analysis and Prevention, Vol. 68, pp. 117-130.

van Leeuwen, J. and J. van Tatenhove (2010), "The triangle of marine governance in the environmental governance of Dutch offshore platforms". Marine Policy, Vol. 34/3, pp. 590597.

Vepsäläinen, A. and J. Lappalainen (2010), Utilization of Incident Reporting in The Finnish Maritime Industry. Publications from the Centre for Maritime Studies, University of Turku A 53.

Walker, C. (2014), Obtaining the green light for "highway monsters": the role of industry selfregulation in progressing vehicle innovation, productivity and safety in the road transport sector. In HVTT13: International Symposium on Heavy Vehicle Transport Technology, San Luis.

Walters, D. and N. Bailey (2013), Lives in peril: profit or safety in the global maritime industry? Palgrave Macmillan, Basingstoke.

Warszawska, K. and A. Kraslawski (2015), "Method for quantitative assessment of safety culture". Journal of Loss Prevention in the Process Industries, 24 September.

Weick, K.E. and K.M. Sutcliffe (2007), Managing the Unexpected: Resilient Performance in an Age of Uncertainty. Jossey-Bass, San Fransisco.

Wiegmann, D., H. Zhang, T. von Thaden, G. Sharma and A. Mitchell (2002), A synthesis of safety culture and safety climate research. University of Illinois, Aviation Research Lab, Savoy.

Vu, T. and H. De Cieri, H. (2014), Safety culture and safety climate definitions suitable for a regulator A systematic literature review. Research report 0414-060-R2C. Australian Centre for Research in Employment and Work, Monash University.

Xue, C., D. Walters and L. Tang (2015), "The Effectiveness of Health and Safety Management in Chinese Shipping: From the Perspective of a Shipmaster's Decision-making Power". In Proceedings of the World Congress on Engineering 2015, Vol II, 1-3 July 2015. Newswood Limited, London.

Yliskylä-Peuralahti, J. and D. Gritsenko (2014), "Binding rules or voluntary actions? A conceptual framework for CSR in shipping". WMU Journal of Maritime Affairs, Vol. 13/2, pp. 251-268.

Zohar, D. (2010), "Thirty years of safety climate research: Reflections and future directions". Accident Analysis and Prevention, Vol. 42/5, pp. 1517-1522. 


\section{Notes}

The twenty-foot equivalent unit (often TEU or teu) describes the capacity of container ships and container terminals. It is based on the volume of a 20 -foot-long (6.1 metre) container.

One serious accident per 100000 movements.

Incident reporting means a systematic way of reporting incidents and near-miss occurrences at workplaces. The terminology concerning incidents is broad and there is a significant amount of variation in the terms found in literature. For example, the IMO uses ten different terms for incidents in its rules, many of which overlap. In this study, incident reporting procedures cover the reports and analyses of non-conformities, accidents and hazardous situations. 
